\title{
14 \\ The dynamics of culture and nature in a 'protected' Fataluku landscape
}

\author{
Sue 0'Connor, The Australian National University, Canberra, Australia \\ Sandra Pannell, James Cook University, Cairns, Australia \\ Sally Brockwell, The Australian National University, Canberra, Australia
}

\section{Introduction}

In his work on 'Landscape and Memory', the historian Simon Schama reminds us that 'landscape is the work of the mind. Its scenery is built up as much from strata of memory as from layers of rock' (1995:7). Focusing upon those elemental physical features evident in the Western landscape tradition, namely wood, water, and rock, Schama examines the layers of social memory and visual representation, to reveal the many historical associations and varied cultural meanings of 'natural' objects and places. In the history of protected area management, most notably exemplified by the 1972 World Heritage Convention, the idea of 'heritage' often mediates the expression of the nature-culture relationship that Schama refers to here (see Pannell 2006a).

Indeed, in recent years, we have seen an increasing number of articles exploring 'the intersections of culture, politics, performance and nature' in customary relationships to land and sea in Indigenous communities in Southeast Asia (Zerner 2003a:xi; Pannell 2006a; also see papers in Zerner $2003 \mathrm{~b})$. At the heart of these papers lies the question of rights and the issue of how Indigenous and other communities can most effectively engage with the processes and institutions affecting their access and use of areas they regard as their ancestrally given homelands. In the discourse of protected area management, one of the more pressing issues is also about the imaginative and material simplifications imposed on the landscape of customary tenure' (Zerner 2003a:12) and upon local people and their practices. As the work of Anna Lowenhaupt Tsing among Meratus Dayaks demonstrated, their disenfranchisement from their forest lands and livelihoods, in part, rested upon the characterisation of these lands as 'wild', and thus free of any prior property claims, making them 'fair game for commercial exploitation' (2003:30). As Pannell has argued, similar simplifications and dichotomous classifications came into play in the fashioning and invocation of 'sasi' as a traditional, Moluccan-based 'sustainable resource management strategy' (Pannell 1997). In the 1990s, 'sasi' was vaunted by environmentalists, government agents, and academics alike not only as a magic cure to the ills ailing eastern Indonesia's declining fisheries, but also as means to address local equity and social justice issues (see Bailey and Zerner 1992; Zerner 1994). As Charles Zerner observed, it didn't seem to matter that the representation of sasi 
as an 'intentionally conservationist institution' was inaccurate (1994:104). What really mattered, however, was the impact of this fiction on the lives of local people, when they were perceived to fail the 'ecologically sustainable' parameters imposed by this reworking of sasi.

With the lessons of sasi in mind, in this paper we adopt a similar perspective to Schama and Zerner (as well as others) in examining the layering and porosity of 'nature' and 'culture' in the emplaced cultural practices of Fataluku people in Timor-Leste. Informed by Tsing's comments about the need to "take very seriously other ways of understanding and making 'rights and 'forests" (2003:27), we also look at the problems of accommodating this world view, and the customary rights and interests associated with it, within the structural frameworks of the nation-state and within newly introduced heritage legislation, where regulations governing land use are predicated not only on the dichotomization of nature and culture, but also upon the separation of these concepts, and often times, upon the disavowal of one at the expense of the other (O'Connor $e t$ al. 2011a). The tensions between the new structures of nationhood and Fataluku understandings of the world also reproduce a higher level duality that exists in Timor-Leste, namely, the division between customary rights and traditional lore and that of parliamentary governance and civil law.

Since the formal achievement of independence in 2002, the government of Timor-Leste has embraced the democratic ideal of statehood for the wider public good and in some areas of the country the government has moved towards the gazettal of land for this purpose (see McWilliam 2011). In 2007, the new nation's first National Park (Figure 1) was declared over an area of some 68,000 ha of land and 55,600 ha of seascape, situated at the eastern end of the island, in the Lautem District. Named after a former Falintil commander, who was born within its boundaries, the Nino Konis Santana National Park commemorates his service and that of the many East Timorese resistance fighters who lived in the forests during the Indonesian occupation, in the period from 1975 until 1999. While the Nino Konis Santana National Park was gazetted primarily on the basis of its 'natural' values (see Whistler 2001; Trainor et al. 2003; McWilliam 2007a; O'Connor et al. 2011a), the Park is home to more than fifteen thousand Fataluku-speaking people, who regard many of the identified 'natural' features of the Park as socially significant places within a wider Fataluku cultural landscape. These sites and spaces range from ancestral settlements, graves and shrines, through to geographic features, such as rock outcrops and freshwater springs, which are mythologically significant or empowered by supernatural or non-human beings; and not least, the forest as whole, which is not only used to extract an extensive variety of resources, but it is also used as the location for the performance of rituals and ceremonies.

The Park also contains a rich and diverse array of evidence of human occupation, dating from ancient prehistoric to historic times. This includes the earliest evidence of modern human colonisation in the Wallacean Archipelago (O'Connor et al. 2002; O'Connor 2007; O'Connor et al. 2010a), the world's earliest evidence for systematic pelagic fishing and the manufacture of fish hooks (O'Connor et al. 2011b), world-class rock art sites, including the oldest known engraving site in Southeast Asia (O'Connor 2003; Lape et al. 2007; O'Connor et al. 2010b), traditional fortified settlements (Lape 2006), excellent examples of colonial architecture, dating from the Portuguese period of occupation, and sites associated with the Japanese occupation of the island during the later part of World War II. Some of these sites have national and even international heritage significance due to their antiquity, rarity, research and/or aesthetic values, but many also hold intense local significance for Fataluku people due to their mythological status, ancestral connections and/or contemporary cultural associations. As the former home to many Falantil freedom fighters, including President Xanana Gusmão, during the period 1975-1999, the Park can also be identified as having considerable local and national value as a landscape of political resistance and social liberation (Pannell and O'Connor 2005). 
Contrary to the ideas underpinning environmental preservation and the creation of nature-based protected areas (see Luke 1995; Katz 1998), to Fataluku people, land which is unoccupied and cultural sites which are not regularly attended are regarded as dangerous places, as the relationship between the human and the non-human world requires ongoing physical interaction and regular ritual communication. In common with so many Indigenous groups around the world, Fataluku people also believe that their cultural practices, rituals and familiarity with the non-human beings which co-occupy their lands are essential to the reproduction of the 'natural' world, now supposedly protected by the declaration of the Nino Konis Santana National Park. This has led to a desire on the part of some Fataluku clan groups now living in the roadside settlement of Tutuala to return to their ancestral homelands within the Park (Figure 1). These are the families, or descendants of families, who were compulsorily resettled by the administration during the Portuguese and Indonesian occupation of Timor-Leste. Their desire to reoccupy ancestral homelands, like so many other Fataluku cultural practices which were previously focused upon the forested region now within the Park, is not regarded by the Ministry of Agriculture and Fisheries (MAF) (formerly Ministry of Agriculture, Forestry and Fisheries, MAFF) as compatible with the Park's existence. In this regard, the MAF aims to curtail residential and agricultural expansion into forested areas, while it currently limits the hunting of forest animals. We argue here that the very policies which exclude local people from occupation and use of the resources within the forested areas of the Park are putting at risk both the cultural sites and the natural resources that they seek to protect.

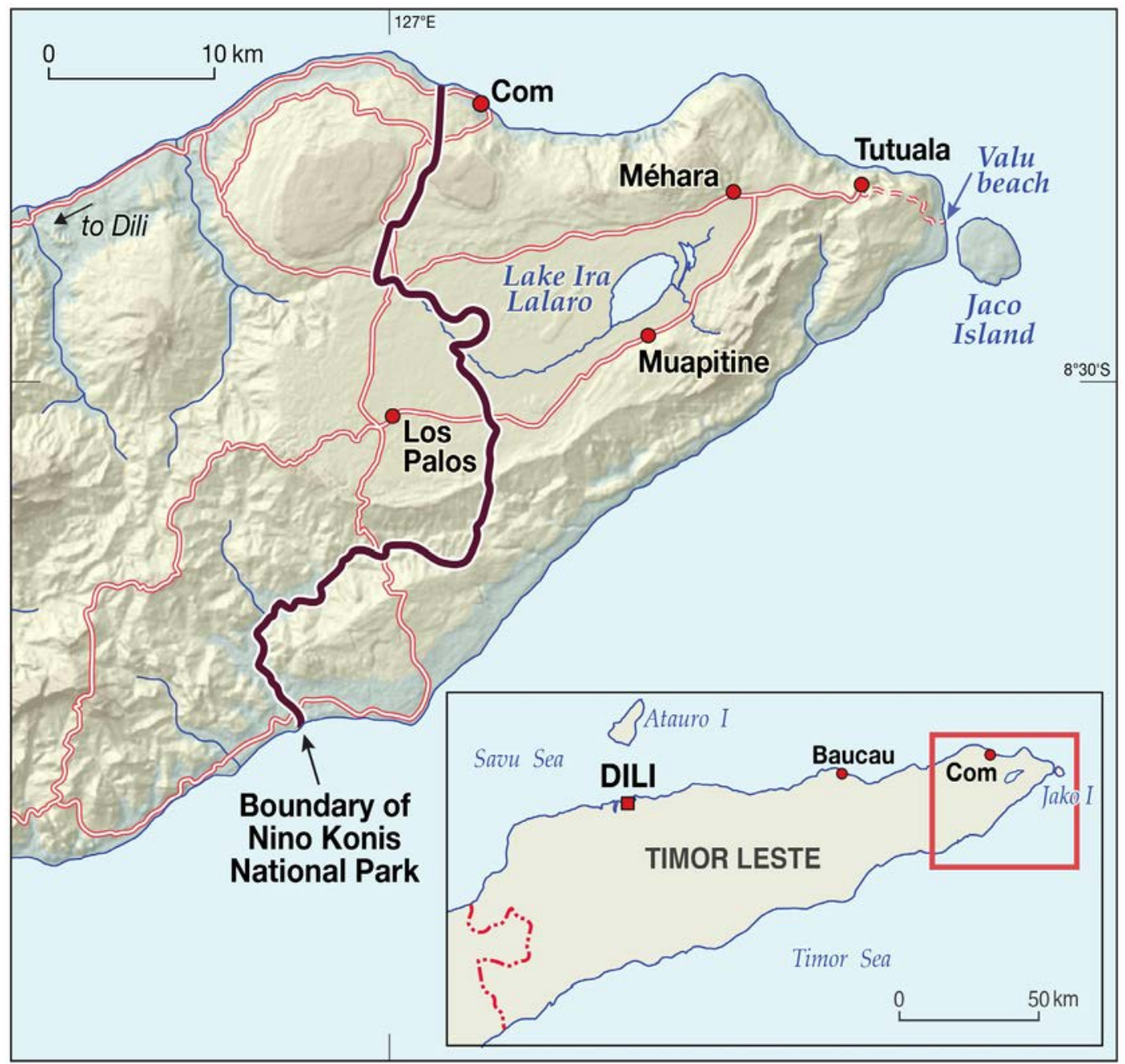

Figure 1. Timor-Leste, Nino Konis Santana National Park and locations mentioned in the text. 


\section{Fataluku people: Living in the Park}

With very few exceptions, the people living within the Park are speakers of Fataluku, a Papuan language. Although the antiquity of Papuan languages in Timor and the relationship of Fataluku to the other Papuan languages spoken in Timor-Leste, being Bunaq and Makasai, is still unclear, it is widely agreed that the Papuan languages are unrelated to the Austronesian languages spoken throughout West Timor and most of the western half of Timor-Leste (Figure 1) (McWilliam 2007b; Schapper 2012).

For the Fataluku residents who live in and around the six villages (suco) now encompassed within the Park boundaries, many of the natural resources of the forest constitute important elements in local subsistence strategies. These communities have few opportunities to participate in the cash economy. For example, $87.7 \%$ of household economic activity centres on food crops and livestock farming, for the most part, based upon shifting mixed crop swidden gardens and the raising of domestic livestock, such as chickens, cattle, water buffalo, pigs and goats (Mau 2010:1) (Figure 2). The daily diet is largely vegetarian, relying on staple crops obtained from swidden gardens, such as maize, cassava, and various kinds of yams and beans (Pannell and O'Connor 2010).

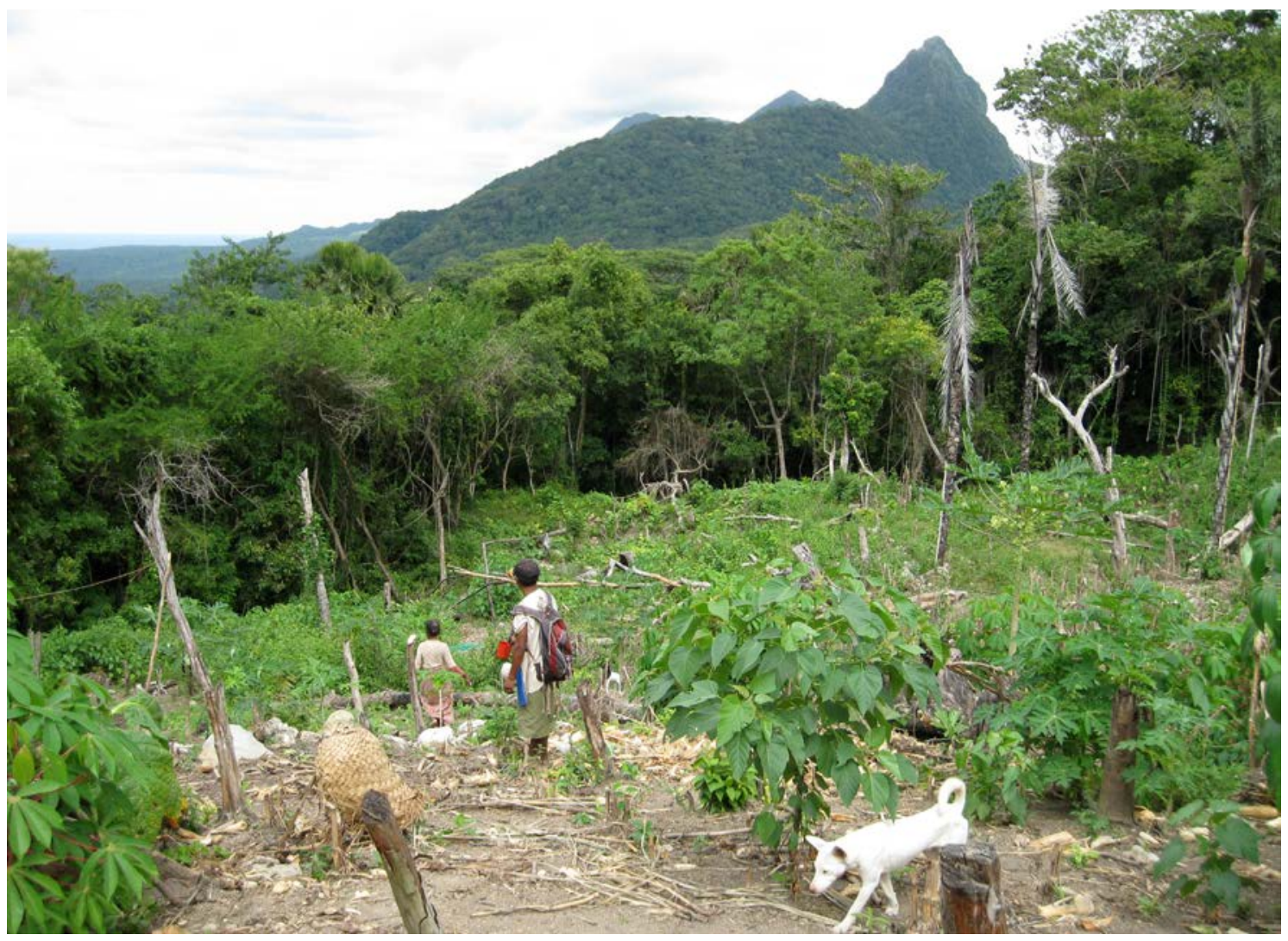

Figure 2. Garden clearing within the forest in the Nino Konis Santana National Park.

Source: Sue 0'Connor.

Hunting is an integral part of the local economy. People rely on the forests for cuscus (a species of possum), monkeys and feral animals, such as deer and wild pigs, to supplement their protein supplies, and these 'wild' resources are particularly important in times of seasonal and politically triggered food shortages (Pannell and O'Connor 2010). Apart from some species of birds (Trainor et al. 2003), bats and small murids, none of the animals that inhabit the forests are endemic to the island of Timor; they are all human introductions brought from areas to the east or west during late prehistoric or historic times (O'Connor and Aplin 2007). Many other kinds of resources, aside from wild game, are acquired from within the Park including plant foods such as nuts, fruits 
and tubers, medicinal species (Collins et al. 2007), bamboo, canoe trees, and wood and fibrous plant materials used for building and for making the diversity of items of material culture used by households every day. In fact, up until the gazettal of the Park in 2007, resources used by Fataluku people on a daily basis were unofficially, but widely, acknowledged by the government's representatives at the regional and district level as being the traditional property of local Fataluku people, in much the same way in which the area of the Park is said by Fataluku people to include their customary lands and waters.

In view of the distance between most of the permanent settlements in the Park and the coastline, few Fataluku communities regularly engage in coastal subsistence activities or rely wholly on marine resources as food staples, although a diverse range of coastal resources from the beach and the sea are exploited on a seasonal or episodic basis (Figure 3). The antiquity of fishing in this region of Timor-Leste, however, is demonstrated by the fish bone assemblage from Jerimalai shelter, located within the Park boundaries, which dates back to 42,000 years ago and which contains a broad spectrum of species including pelagic and reef fish (O'Connor et al. 2011b).

The few groups of Fataluku people who specialise in fishing have boats and temporary shelters located in the Park at Valu Beach, at the eastern point of Timor island (Figure 4). Today this activity seems to be primarily undertaken by a local fishing co-operative, whose members catch and cook fish for the tourists who drive from Dili to spend the weekend camped on the beach, or stay in the nearby eco-resort, which was built shortly before the Park was gazetted.

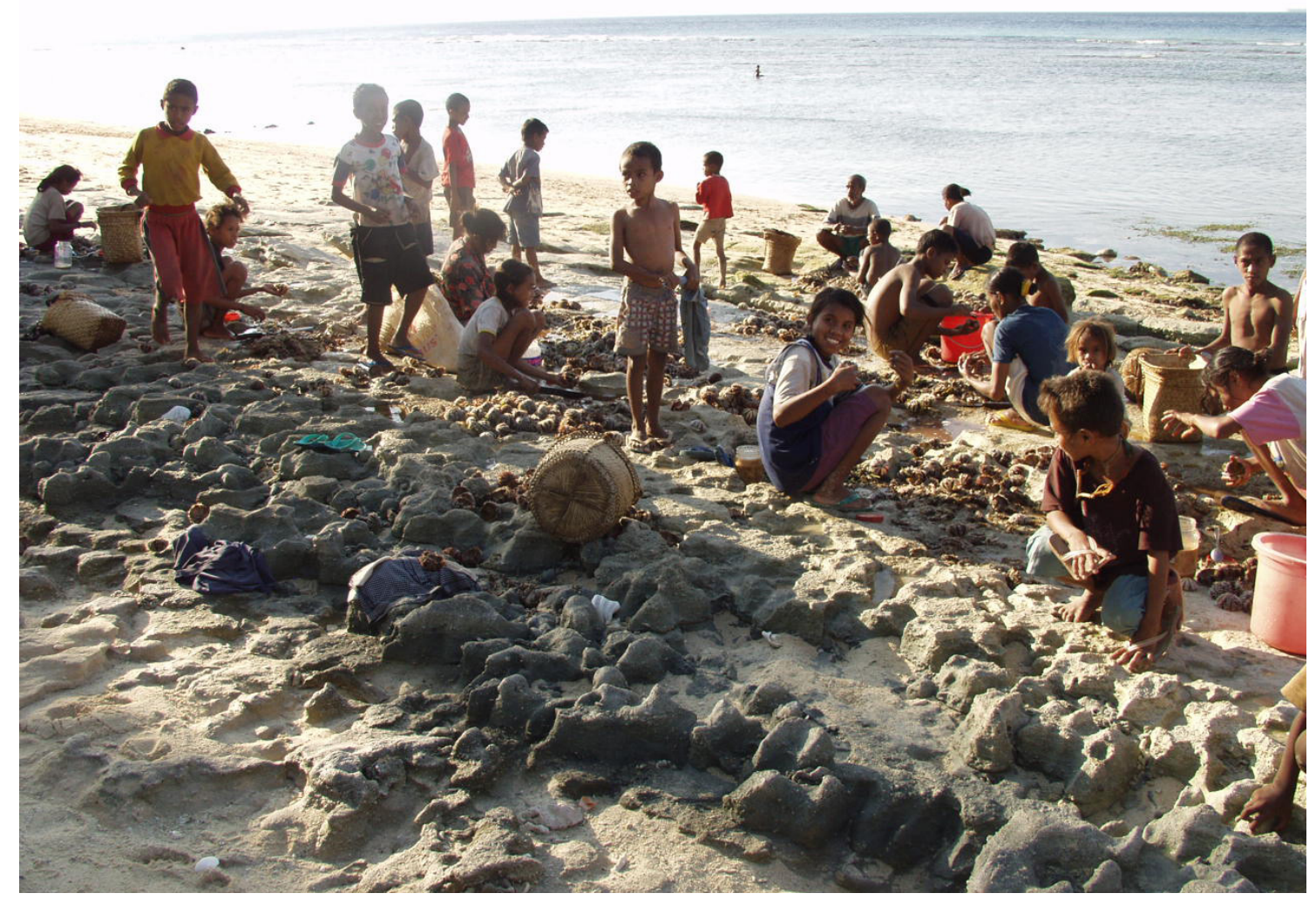

Figure 3. Children collecting and processing sea urchins at a beach near Com within the Park.

Source: Sue 0'Connor.

A number of other marine resources are collected intensively on a seasonal schedule from the coastal zone and the seas contained with the Park. At times of extreme low tide, whole families camp overnight on the beach and comb the reef using kerosene lanterns or torches to collect the 
multitude of edible marine creatures. In February and March, the sea worms (mechi) spawn. This event lasts only two days in each month but is a time when the local communities come together (see also Palmer and Carvalho 2008).

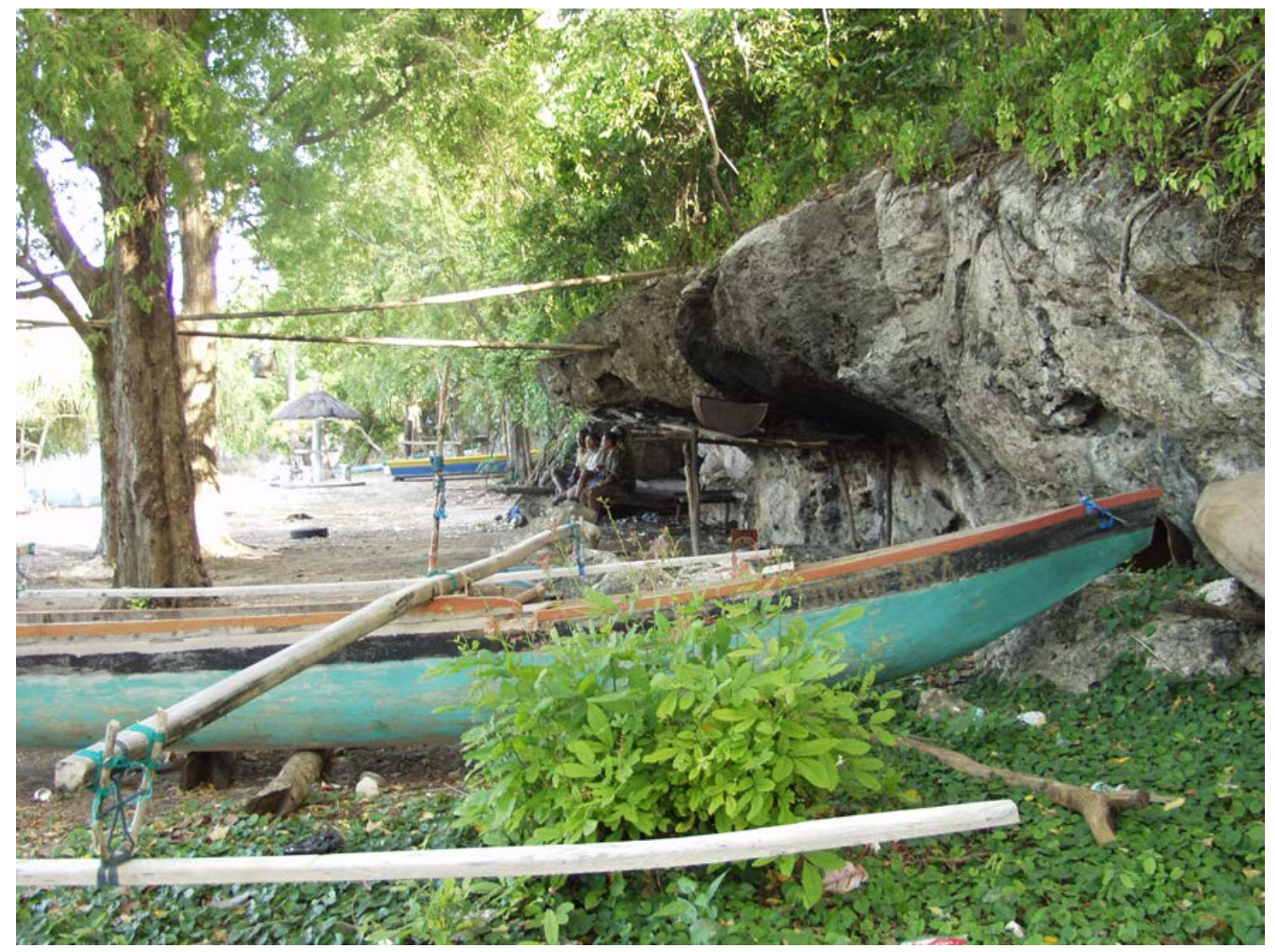

Figure 4. Valu Beach. The boats of the fisherman are kept at the back of the beach and storage racks and caverns for their possessions are made in the limestone caves at the back of the beach.

Source: Sue 0'Connor.

Green sea turtles come onshore at Valu and the adjacent beaches to lay their eggs seasonally. Prior to the establishment of the Park, some families would camp on the beaches when this event was imminent and keep watch throughout the night in order to collect both the eggs and capture the nesting turtles. Hunting of turtles and the collection of turtle eggs is now prohibited under the rules governing use of the Park.

This all too brief description of Fataluku livelihood needs and ecological knowledge regarding the forests and seas now encompassed by the National Park, in part, gives some idea of the social and economic significance of this landscape to local communities, located in and around the protected area. However, as we discuss in the following sections, the significance of the Park area to Fataluku people extends beyond their material use of forest and sea-based resources.

\section{The socio-political dynamics of documenting heritage values in the Nino Konis Santana National Park}

The Nino Konis Santana National Park is administered by the 'Protected Areas and National Parks, National Directorate of Forestry', within the MAF. It includes approximately $300 \mathrm{~km} 2$ of lowland tropical and monsoon forest surrounding the Paichao mountain range - one of the largest continuous tracts of forest on the island of Timor. The Park also includes coral reef 
areas surrounding Jaco Island, which have been identified as possessing high biodiversity values (Edyvane et al. 2009a). It was largely for the values of the reef, the forest and its birdlife that the Park was declared. However, as noted above, the Park is a far cry from a 'pristine block of natural heritage values and primary forest' (McWilliam 2007a:168). As previously mentioned, the Fataluku communities resident within the Park depend on its land and resources for their ongoing livelihood. The Park also encloses an existing cultural landscape of Fataluku named places and ancestral spaces (McWilliam 2011; O’Connor et al. 2011a). Indeed, as McWilliam (2007a:168) notes, 'ironically much of the forested area is composed of former swidden gardens and settlement sites. Its existence as a contemporary canopy forest is, to a significant degree, the result of the reluctant disengagement of local Fataluku farming communities in response to external pressures applied by successive colonial governments, especially in the form of resettlement policies and restrictive security arrangements'.

The Nino Konis Santana National Park has been identified as a 'Category V Protected Landscape/ Seascape'. According to IUCN's (World Conservation Union) Guidelines for Protected Area Management Categories, Category V Protected Landscape/Seascapes are defined as an 'area of land, with coast and sea as appropriate, where the interaction of people and nature over time has produced an area of distinct character with significant aesthetic, ecological and/or cultural value ...' (IUCN 1994:22). Reflecting new ways of imagining forests and seas, beyond the historical classification of them as 'natural' or 'wild' spaces (see Tsing 2003), and trying to accommodate human uses, key management objectives for 'Category V Protected Landscapes/Seascapes' include the maintenance of the 'harmonious interaction of nature and culture', providing support for 'lifestyles and economic activities which are in harmony with nature' and the 'preservation of the social and cultural fabric of the communities concerned' (IUCN 1994:22). In this respect the IUCN 'Protected Landscape/Seascape' category has much in common with the World Heritage category of 'Cultural Landscapes' (UNESCO 2005:14) and thus the Park should be able to accommodate the full spectrum of cultural activities undertaken by local communities.

Although there have been a number of surveys within the Park, conducted under the auspices of the MAF (e.g. Edyvane et al. 2009a, 2009b), they have primarily aimed at assessing the natural values and biodiversity of the Park, and they have only fleetingly dealt with cultural sites; with a focus mainly on churches, built during the Portuguese era (Edyvane et al. 2009b:41-49). Archaeological sites are not mentioned at all, although 'Archaeology' is incorporated as a heading under 'History and Development', in an example of a protected area management plan for the Park (Edyvane et al. 2009a:95). To date, no systematic cultural mapping has been undertaken with local communities within the Park. However, as noted above, archaeological and anthropological research by O'Connor, Lape, McWilliam, Pannell, Spriggs, and Veth, undertaken between 2000 and 2005, has identified the area as having a range of outstanding cultural heritage values at the local, national and international level (cf. O'Connor 2003; Spriggs et al. 2003; O'Connor and Veth 2005; Pannell and O'Connor 2005; Veth et al. 2005; Lape 2006; McWilliam 2006; O'Connor 2006; O'Connor and Pannell 2006; Pannell 2006b; O'Connor and Oliveira 2007; O'Connor et al. 2010a and 2010b; O'Connor et al. 2011a and b).

In 2006, two of the authors of this paper, O'Connor (an archaeologist) and Pannell (an anthropologist), were commissioned by the NSW Department of Environment and Conservation (DEC NSW), in partnership with the then Ministry of Agriculture, Forestry and Fisheries (MAFF), to undertake a desktop study of cultural heritage places within the area under consideration for inclusion within the Park. ${ }^{1}$ This study was to be provided by DEC to the MAFF

\footnotetext{
1 The boundaries on the map provided to O'Connor and Pannell by DEC NSW officers prior to the desktop were provisional, however, the boundaries of the Park as gazetted were not greatly different from the boundaries as provisionally mapped and the sites we discuss here are within the NCSNP boundaries as gazetted.
} 
in 'East Timor' as a preliminary background document on the cultural heritage values of this area. The DEC consultancy brief to the authors stated that the desktop study was to be only the first stage of a cultural heritage survey, and would be followed by a field-based study. Although the desktop report produced by O'Connor and Pannell (2006) was based on archaeological and anthropological field work and research conducted over many months and years in this region, and while informed by 'the knowledge, memory or interest of the local informants involved' (O'Connor and Pannell 2006:5), this research was, largely driven by the context of specific academic research agendas. As we made clear in the report to DEC, the archaeological surveys undertaken were not 'designed on the basis of 'sampling' of landscape units or total area' and they were not 'in any way systematic' (O'Connor and Pannell 2006:5). In a similar fashion, the anthropological research undertaken with Fataluku people in this area by no means exhausted the tangible and intangible cultural heritage values of the landscape within the Park.

Basically, archaeological research involved community consultation in areas likely to contain the types of sites of interest to archaeologists. In this respect, we would describe caves, rockshelters and fortified sites to those members of the local Fataluku community who had been nominated to work with us. These people usually included representatives of the state, nominated by the chefe de suco ('village head'), and representatives of the landowning ratu, ${ }^{2}$ nominated by senior ratu customary law and ritual leaders (also referred to here as the 'lord of the land'). Our Fataluku counterparts then 'identified sites [being caves, rockshelters and fortified sites] with which they were familiar and which they thought might match our description, and which were regarded by them as appropriate for us to record' (O'Connor and Pannell 2006:5). Having established relationships with particular individuals/landowning ratu members in areas with identified archaeological research potential, the physical loci of our research was largely confined to these areas. Our report made clear that the research had been focused on the sub-district (posto) of Tutuala, the village (suco) of Méhara and its associated hamlets (aldeia), and upon the landscape surrounding the harbour-side village of Com (suco). Thus, while some areas were extremely well surveyed and areas of high cultural values known to ratu members were documented, other areas of the Park were not even visited and, as such, community consultation was not undertaken in respect of these particular areas. The report and an electronic site register, containing site locations, descriptions and informant contacts for over 200 sites was given to DEC NSW in 2006. The 2006 report advocates that, 'further community-based research on the cultural values of the Nino Conis Santana National Park is required and strongly recommended' (2006:4). It also recommended that the Ministry (MAFF) undertake consultation and engage in a partnership with the Office of the Secretary of State of Culture within the Ministry of Education (then 'Education, Culture, Youth and Sport'), whose officers had independently recorded a number of cultural heritage sites within the area identified for the Park, and who held a site register dating from the period of Indonesian governance, when their Ministry was established.

Correspondence with DEC officers informed us that the field survey which was to follow the desktop study would be delayed until late in 2006 due to the pressures and work commitments of the Timor-Leste MAFF staff but that it would follow later in the year. Fieldwork was then delayed by political turmoil in 2006 and 2007. To the best of our knowledge, no cultural heritage surveys or cultural landscape mapping exercise has yet been undertaken by the Ministry, or under their remit since this time, apart from a five day survey by Edyvane and McWilliam in 2008, which did not extend east of Com (Edyvane et al. 2009b).

2 McWilliam (2011:65) defines ratu as 'a dispersed, exogamous, paternal 'house of origin' and as the 'fundamental social institution that informs the organization of Fataluku society'. 
In 2009 O'Connor, Aplin, Dos Santos and St Pierre carried out archaeological surveys aimed at locating palaeofaunal deposits and speleothems which might provide information on biological extinctions and past rainfall regimes in this part of Timor-Leste. In the course of this reconnaissance, a number of ancient petroglyphs were identified and documented within Lené Hara cave (O'Connor et al. 2010b). O'Connor and McWilliam also undertook a brief forest survey to locate stone walled fortified settlements in the inland, densely forested areas of the Park. The 2009 survey was carried out under a research permit from the MAF (previously MAFF), but it was not instigated by that Ministry.

\section{The layering and porosity of nature and culture in Fataluku landscapes}

Of the 200 plus sites recorded to date within the Park, most have contemporary socio-cultural significance to Fataluku people (O'Connor and Pannell 2006). They include: a wide range of ritual and mythological sites, specialist subsistence/resource sites, rock art sites, occupation sites including caves and shelters, fortified walled village sites, surface scatters of stone artefacts and/ or pottery and shell; burial sites and water sites. Almost none of these site types are mutually exclusive and in almost all cases they are integral to contemporary cultural practice. For example so called 'ritual sites' include settlement and forest-based locality guardian/sacrificial sites, ancestral landing or first footprint sites (ia mari tulia), the 'stone boats' of immigrant ratu (loiasu mataru), ancestral graves (calu lutur or narunu) located within and outside of former settlements, 'increase' sites associated with warfare and past headhunting ventures, constructed signs or markers, which are said to be empowered, and which warn strangers that particular forest trees or other natural products are 'owned', and ancestral mythological sites associated with the first autochthonous people to emerge with the land and their sacred animals. In addition, there are a number of individually named stones or 'natural' landscape features, which feature in local ratu origin myths, and which serve to mark land boundaries or commemorate significant past events (O'Connor and Pannell 2006:35). Ritual sites are found throughout the Park - in old villages, caves, near water sources, and throughout the forest. These sites are often physically marked and are identified by Fataluku people as sacred or téi, being places where non-human beings are said to live and influence people's action in the immediate locale.

Sites are not regarded as 'cultural archives'; rather many are seen as 'alive' or as animated beings in the landscape and in peoples' lives, past and present. In this regard, they are said to have agency and efficacy. They connect the present to the past, the creation of the land and the ancestors to today, and they may assist or act against humans. According to local people, these kinds of sites do not need heritage protection. Indeed, local beliefs posit an inverse relationship to that proffered by environmental conservation measures, whereby these téi ('hot' or 'sacred') sites are acknowledged as empowered to provide protection for humans and the environment in general. While, the MAF may not regard these sites as having 'national' significance, being the cultural heritage of just one of the many ethnolinguistic groups in Timor-Leste, from the point of view of Fataluku people, some of these sites, such as Ili Kérékéré, a large rock overhang containing painted art and ritual sites, are considered to be the source of all the peoples and lands comprising the island of Timor and they are thus regarded by Fataluku people as of manifest national significance (see Pannell and O'Connor 2013).

As well as showing that there are large numbers of socially and culturally important places within the Park, the research summarised in the report to DEC NSW demonstrated that the division between nature and culture, which so often underpins the creation and management of protected areas, is not meaningful in terms of Fataluku people's beliefs and their understanding of the local environment. As previously indicated, the environment holds multiple levels of meaning for Fataluku people. Many of the so-called 'natural' features found within the Park are ascribed 
culturally specific names. Names for an identified area or geographic feature often relate to the names of ancestral settlements situated within the area. Conversely, cultural sites or former settlements may take their names from topographic features in the landscape, which in turn have mythological significance. For example, the former settlement of Mua Mimiraka, which also gives its name to the surrounding area, takes its name from the 'red' (mimiraka) 'earth' (mua) found in this locality. Along the northeast coast, from Tutuala to Tanjung Téi ('Cape Hero'), locales are also known by the names ascribed to the uplifted limestone terraces, identified as seven distinct levels or téni (O'Connor and Pannell 2006:8). In fact, the whole island of Timor is anthropomorphised. Jaco Island (Totina) is identified by Fataluku people in Tutuala as the "head of the land", while the rest of the island constitutes the "body" (O'Connor and Pannell 2006:16). In the following section, we provide some further examples of significant Fataluku sites and landscapes within the Park and discuss the ways in which nature and culture exchange and interact in the agency of these places.

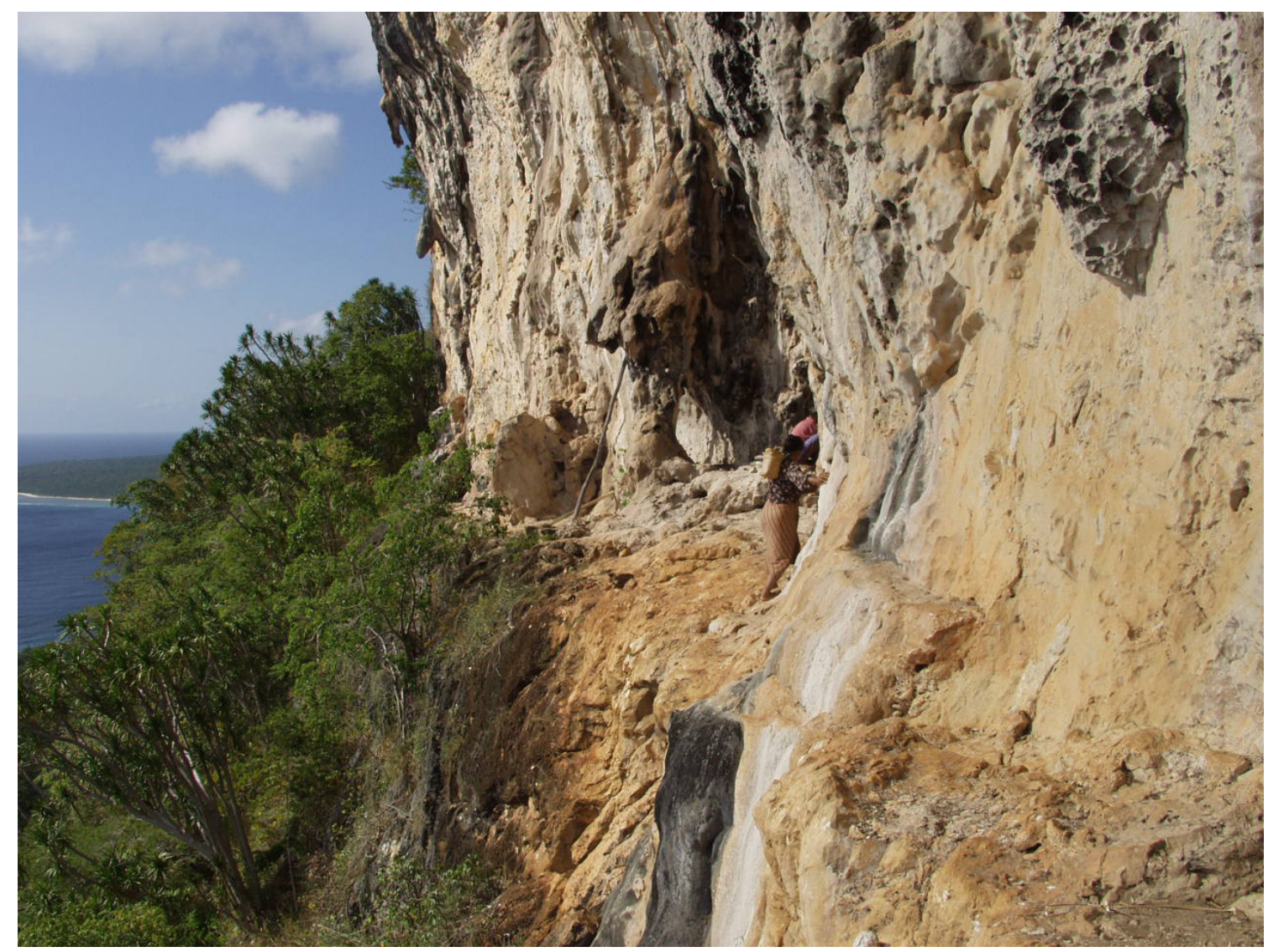

Figure 5. lli Kérékéré shelter overlooks the sea. One of the new téi posts can be seen in the centre of the cave opening.

Source: Sue 0'Connor.

\section{In the beginning: The creation of Fataluku landscapes}

Fataluku mythology holds that after the initial creation of the earth, and the coming into being of the first man and women, who are said to have given rise to the original Tutuala-based ratu, other settlers came from across the water by boat. They were attracted by large candles made out of bee's wax gathered from the honeycombs hanging from the entrance of the rockshelter Ili Kérékéré (Figure 5). Out of this wax the ritual and ceremonial head of the original clan group or the 'lord of the land' (mua ocawa) fashioned candles, which he placed in the entrance of the 
shelter facing out to sea. The candles were lit as a sign that this far-eastern part of the island was now occupied. Following the lighting of the candles, and their sighting by people situated further east, new settlers came from across the sea and, according to local traditions, they were given the right to farm certain tracts of land and form new clan or ratu groups (Pannell 2006b). In the village of Tutuala, more than 24 ratu groups have been recorded. All but one ratu is acknowledged as originating from elsewhere, notably from one of the many islands situated to the east and northeast of the island of Timor, which now form the Province of Maluku, Indonesia. Tutuala Ratu is identified as the autochthonous ratu in the village, and senior people in the ratu are acknowledged as the 'lord of the land' (mua ocawa) of the Tutuala region. This position carries with it many ceremonial duties and obligations (O'Connor and Pannell 2006:12), including the maintenance of ritual sites in the rockshelter known as Ili Kérékéré.

\section{Ancestral landing sites}

The ancestral, 'first landing sites' of the immigrant groups are often marked by 'stone boats'. These limestone outcrops, located along the coast, are identified by Fataluku people as actual boats that turned to stone after the arrival of their ancestors. With one exception, all of the stone boats we recorded within the Park are naturally ocurring rocky outcrops, albeit sometimes augmented with ritual platforms and placed objects or offerings. The one exception is the stone boat belonging to members of Ratu Koawatca. Reminiscent of the stone boats found in the Tanimbar Islands in Maluku (McKinnon 1991) this is a built structure made from massive blocks of coraline limestone, located at Oirata Latamoko. It is identified as a representation of the ancestral landing site and original boat of Koawatca ancestors at Manuméri Hoiku. The boatshaped stone arrangement is also identified as the 'grave' of the first ancestors of this ratu.

\section{Téi}

Throughout the forests and former settlements of the Tutuala region, locales may also be known by the name of an individual téi site. Téi sites, which mark the presence of non-human entities, are considered to be inherently dangerous, and they are associated with a range of protocols and prohibitions (see Pannell and O'Connor 2013). Téi beings are acknowledged by Fataluku people as being able to transmogrify into a number of zoomorphic forms, or even human forms. In the district of Lautem, they are marked by a specific configuration of physical structures, most commonly by platforms built of layered stones or coral blocks, and a central carved wooden post, a plain, upturned tree root, or even a stone plinth (Figure 6). Of all of the Fataluku sites we recorded, téi occupied sites best embody the conceptual ambiguity or porosity of 'nature' and 'culture', 'wild' and 'domestic' in Fataluku beliefs. These unpredictable, shape-shifting entities are said to "guard" areas and their associated ratu members from strangers and sickness, however, if transgressed or neglected they may cause illness, madness or death. According to Fataluku beliefs, they must be regularly visited by ratu members, who are required to 'feed' them with rice, eggs, palm spirit and the meat of animals, such as pigs sacrificed for this purpose. These ceremonies are credited with promoting fertility and well-being, not just for humans, but for the environment as a whole. Entering settlement sites and all other places identified as, and marked by téi, without the custodial ratu member(s), who can speak to the téi being, is regarded by local people as dangerous, and invites all manner of catastrophes (Pannell 2006b; McWilliam 2011; Pannell and O'Connor 2013). Areas of the landscape without people, and where such rituals have been neglected, are similarly dangerous. As such, the cultural beliefs and social practices associated with téi have wider ecological effects. As this suggests, for Fataluku people, nature and culture do not exist as separate realms of meaning or practice. For them, the landscape of the Tutuala region bears testimony to the indivisible relationship that exists between the physical environment and local traditions, between nature and culture (O'Connor and Pannell 2006:10,12). 


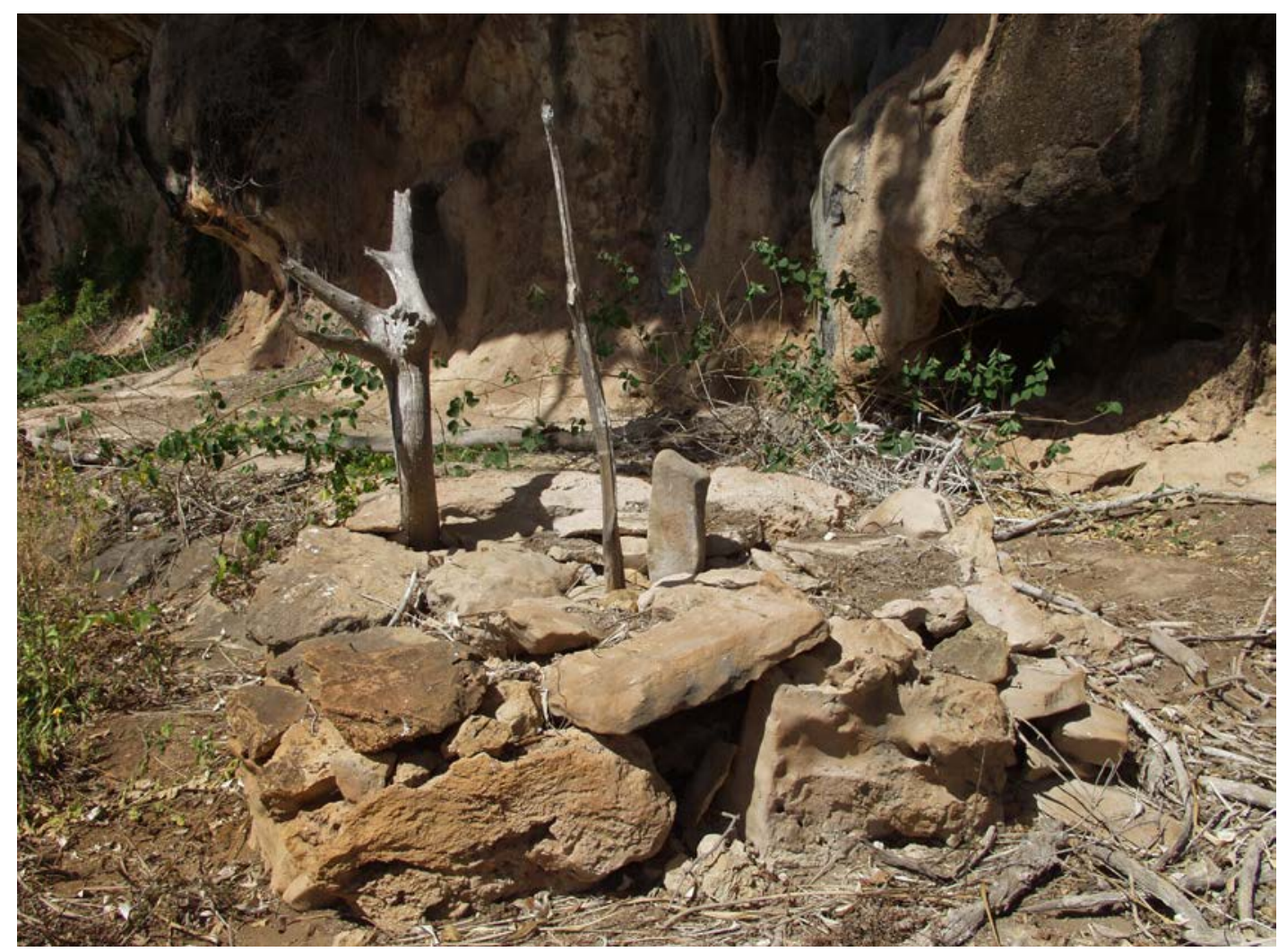

Figure 6. Téi at Moa Mimi raka.

Source: Sue 0'Connor.

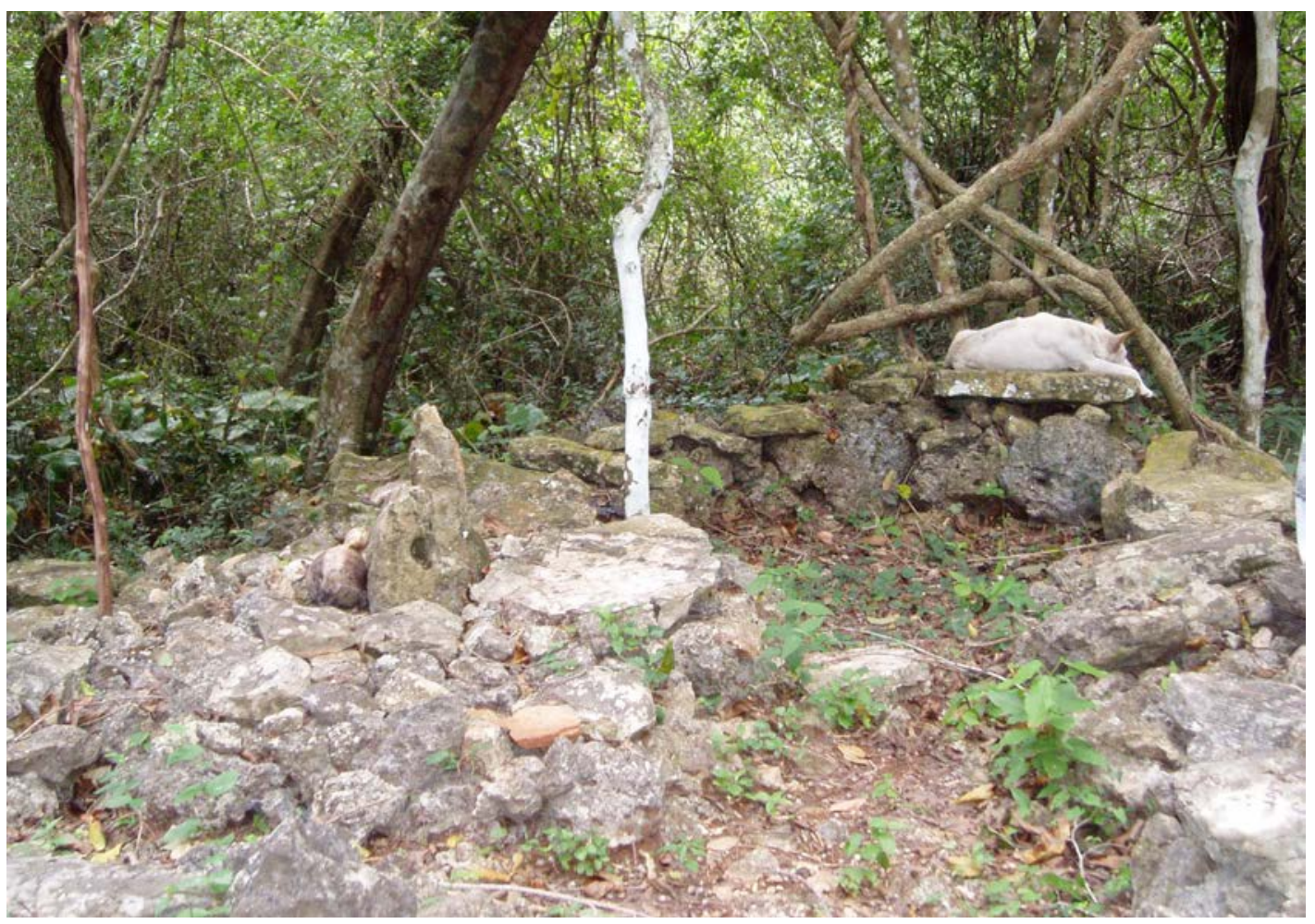

Figure 7. The president téi Titiru.

Source: Sue 0'Connor. 
This is well illustrated by our informants' description of the efficacy of the 'president' téi at Titiru, situated near Ili Kérékéré rockshelter (Figure 7). The téi at Titiru is said by members of Tutuala ratu to be the 'biggest head and bones' (téi ilafai chau hafa) of all 'the téi in Timor'. At the centre of the Titiru stone platform stand two stones, the larger of the stones is said to be the husband of the smaller one. While identified as 'human', this téi is said to be able to shape-shift and it may appear in many forms. The language of statehood is further extended to a number of other nearby téi, which are said to act as the 'deputy' and the 'commander' of Titiru. While the identification of this téi as the 'president' captures its paramount rank in the local order of téi, it also links it to the political struggle by the people of Timor-Leste for independence.

For Fataluku people in Tutuala, the téi at Titiru is ultimately responsible for the defeat of the Indonesian military and various militia groups in the later part of 1999. A desperate Xanana Gusmão is said to have personally requested assistance from the present 'lord of the land' to dispel the foreigners. Upon receiving this request, and with a photograph of the Falantil leader in hand, the 'lord of the land' sacrificed a pig at Titiru in September 1999 and requested the téi to emerge from the earth and take action against the Indonesians and others who were supporting them. Out of its hole, the téi started to 'eat' the enemy, while Xanana is said to have been imbued with the thoughts and power of the téi, the two creating an unbeatable front to the Indonesian forces. When the Indonesians left, the 'lord of the land' returned to Titiru and sacrificed another pig to 'calm' the téi down and entice it to enter its hole once again, satiated with food and drink, and the 'blood and flesh' of the enemy. As a postscript to this event, Xanana Gusmão visited Tutuala in 2005. The then 'lord of the land' had recently replaced the carved téi posts, which had been stolen from Ili Kérékéré during the Indonesian occupation. A ceremony was held at Ili Kérékéré to mark the occasion and the role of Fataluku people and the empowerment of their traditions in the national victory (Figure 8).

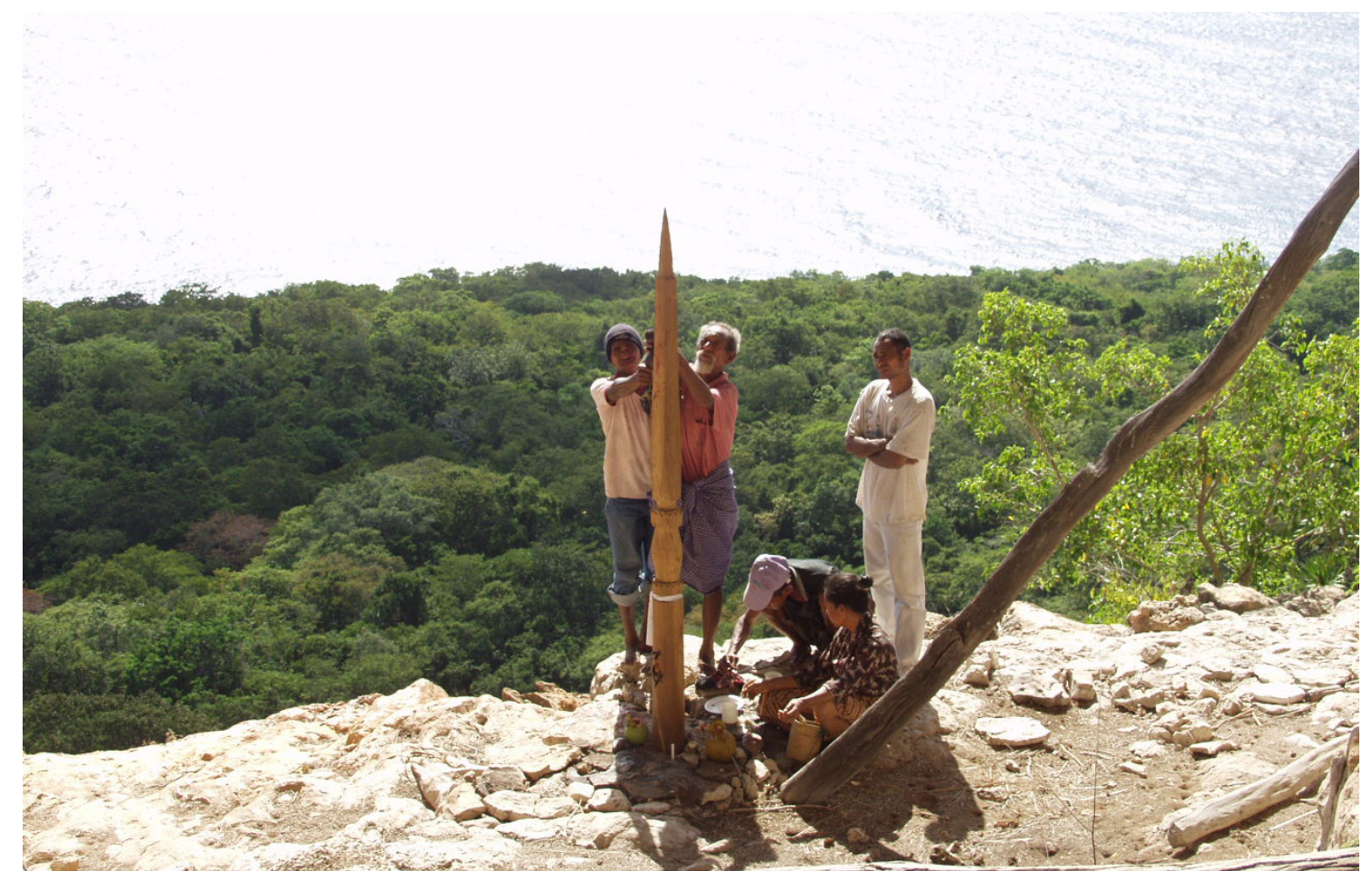

Figure 8. Ceremony following the replacement of a new téi post at lli Kérékéré.

Source: Sue 0'Connor. 


\section{Lupurasa}

Throughout the Fataluku area, important subsistence resources such as lontar palms (kakala oco), bamboo stands, coconut palms, former garden sites (pala) and even forest trees with large honey combs or those designated as future building material, may be marked by ritual signs called lupurasa. According to Fataluku informants, ratu groups possess their own distinctive lupurasa signs. These may include wooden structures used to hang young coconuts, monkey skulls or fragments of woven cloth known to be associated with a particular ratu. In their simplest form they may be merely tied to the trunk of the tree. Lupurasa warn others against using or taking the resources they mark. Lupurasa are ritually empowered by senior men of the ratu group. Ignoring their warning is said to result in injury, sickness, and sometimes death (O'Connor and Pannell 2006:36). Lupurasa provide a clear case where the distinction between nature and culture blurs. Trees so marked may be naturally occurring forest species, for example, a tree designated for future use as a canoe. However, as it will take many generations to mature, the tree may be passed down as inherited property. This provides a cultural dimension to the concept of a 'biodiversity bank', as resources thus identified are regarded as cultural repositories for future social uses.

\section{Rock art}

More than 25 painted rock art sites and one ancient engraving site have now been recorded within the Park boundaries (O'Connor 2003; Lape et al. 2007; O'Connor et al. 2010b). No doubt many more await discovery. The rock art is predominantly found on the walls of the uplifted limestone terraces which overlook the sea, but some is also located in the deeper darker areas of caves. Although they can identify and they have names for many of the painted motifs, our Fataluku informants do not regard the rock art as resulting from human agency. They believe that it pre-existed the advent of humans, spontaneously appearing 'in the beginning,' at the same time as the first land emerged from the sea.

The exception to this are the images of boats which are said to depict the craft of arriving foreigners who were welcomed by the first 'lord of the land'. These were reproduced on the walls of the cave to show that people had arrived and they had been allowed to settle (Lape et al. 2007:4). Exactly who reproduced the boats on the walls is somewhat vague and usually meets with the response, 'the ancestors'. The status of the dominant motifs, small human anthropomorphs shown in a variety of active poses often holding weapons, is also somewhat vague (Figure 9).

The rock art motifs readily identified by Fataluku people include boats, horses, cockerels and recurrent geometric motifs referred to as 'eagles wings', 'poko' and 'faria'. Poko are one of the most commonly occurring geometric motifs. They are made up of a symmetrical arrangement of joined sets of concentric semi-circles or chambers with a feather or rayed line emanating from the upper part of the central form. They are sometimes elaborate and occur as alternating bands of black, red and yellow and sometimes simply in red pigment. Poko are rather obscure. They are said to represent a type of sacred receptacle which is no longer used. Rayed circles are another common motif and are often identified as faria, the Fataluku word for eye blinkers on horse bridles. Elaborate forms again use alternating bands of colour (O'Connor 2003). The reproduction of some of these motifs by the original autochthonous ratu is permitted 'in accordance with the ancestors' and they are woven into sacred clothes to be exchanged at marriage ceremonies and worn on ceremonial occasions. Some motifs are also carved into the wooden facing boards of the ratu houses and reproduced on modern concrete graves (Figure 10) (O'Connor and Pannell 2006; O'Connor and Pannell 2013). 


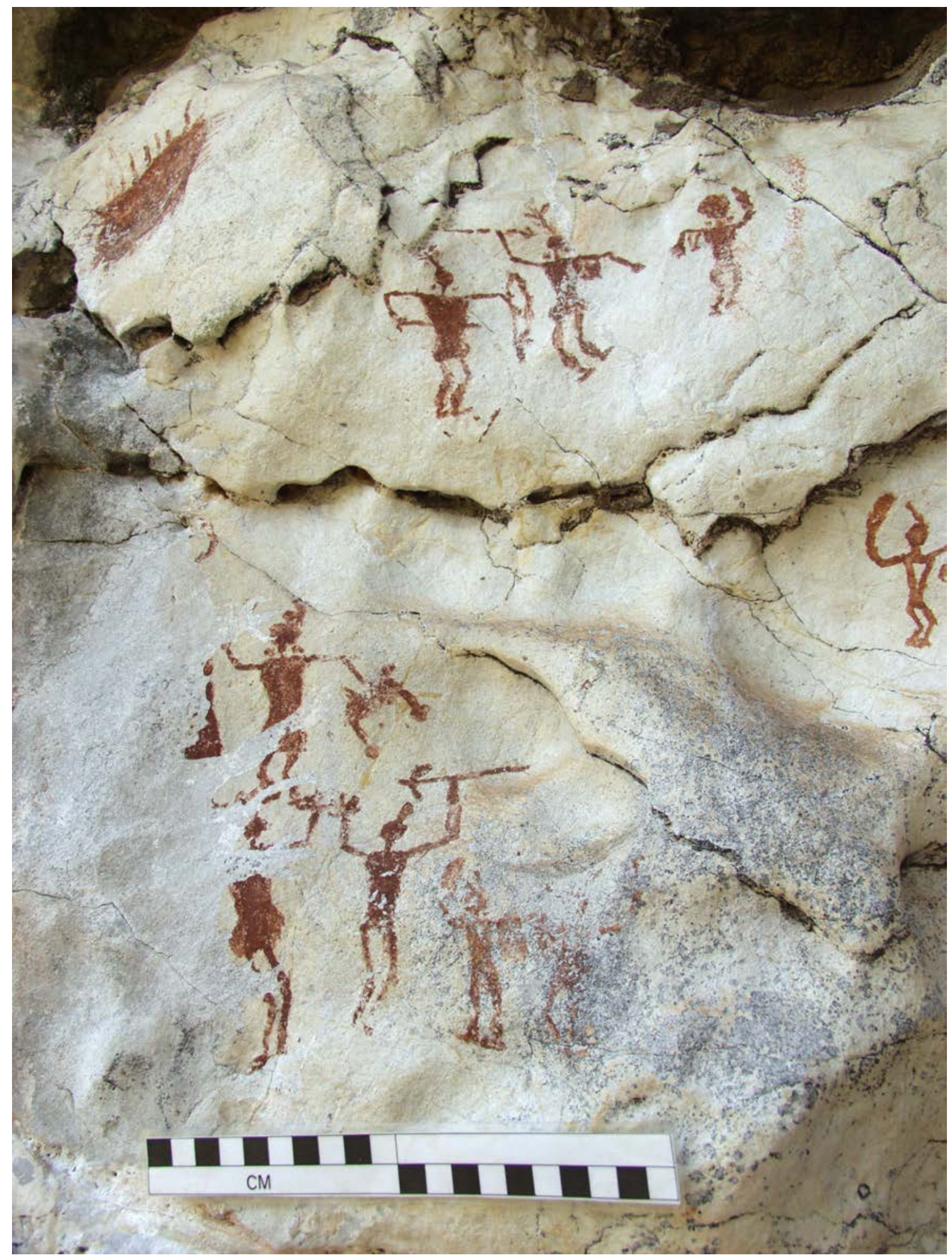

Figure 9. Rock art at Suntaleo. These small human figures are shown holding a variety of weapons including spears and a bow and arrow. They are painted in red pigment.

Source: Sue 0'Connor. 


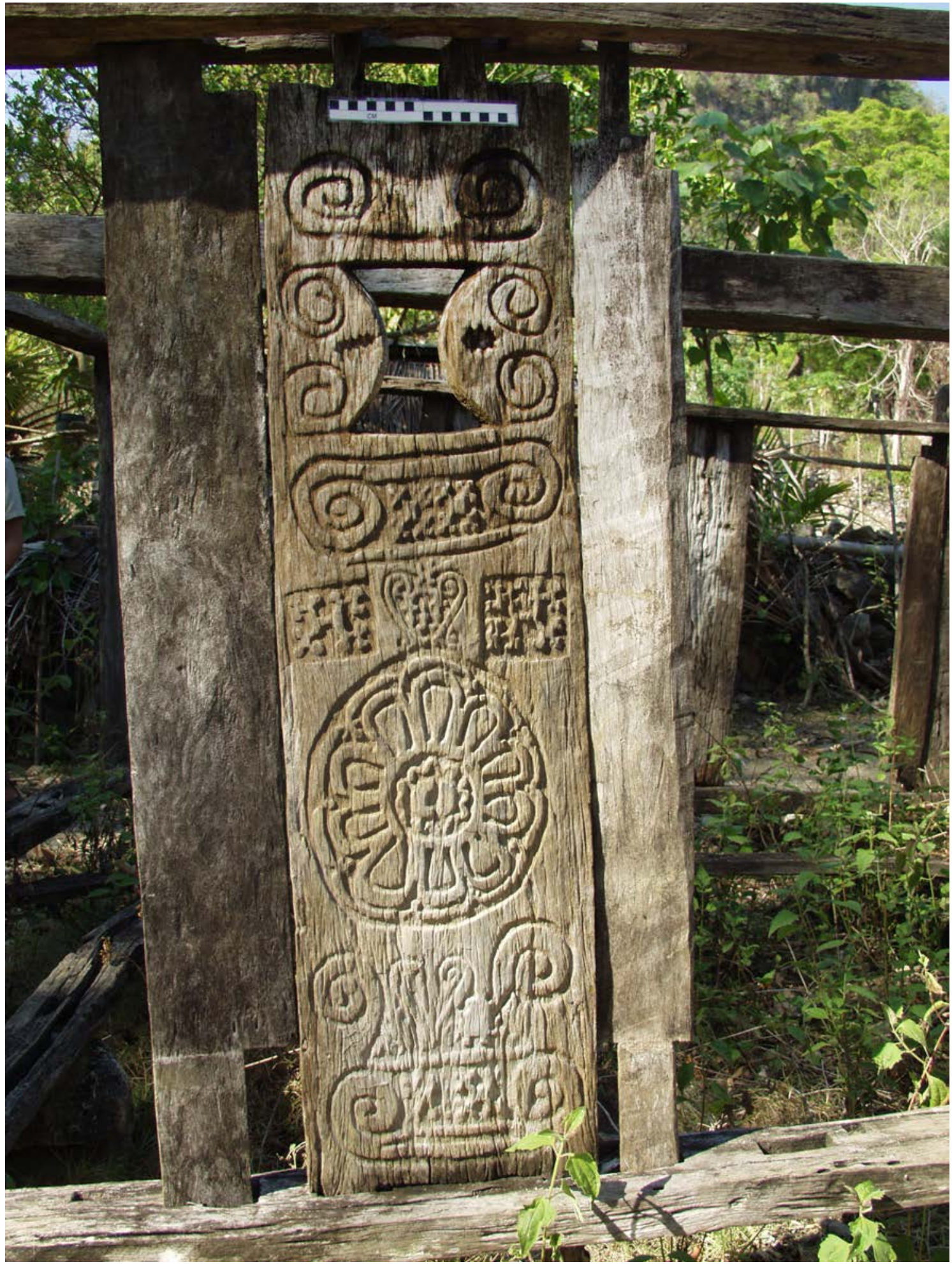

Figure 10. Detail of carved geometric designs on a derelict ratu house in the Nino Konis Santana National Park. The maintenance and use of these sacred houses was actively discouraged during the Indonesian occupation of Timor-Leste.

Source: Sue 0'Connor.

In 2009, a number of extremely weathered petroglyphs, in the form of human faces, were discovered in Lené Hara cave within the Park. Although archaeological excavations and rock art recording at this cave has a long history, beginning with Portuguese exploration (Almeida and Zbyszewski 
1967), the petroglyphs had escaped notice by researchers and they were also apparently unknown to the traditional owners. Their discovery was interpreted by Fataluku people as the outcome of a 'supernatural' event in which the ancestors revealed themselves (O'Connor et al. 2010b). As they were carved into speleothems, the engravings were able to be dated by the Uranium Thorium dating method and proved to be over 10,000 years old (O'Connor et al. 2010b).

\section{Occupation sites}

This category includes rockshelters and caves (veraka) used in prehistory and during the Japanese and Indonesian occupation of the island, as well as caves occupied by ancestral figures, téi , and other spirit figures, former walled settlements (lata irinu) and other old villages (lata), and surface concentrations of shell, stone and pottery.

\section{Caves and rockshelters}

The Park includes extensive areas of uplifted limestone and caves and rock shelters occur throughout it. These include some of the most scientifically significant sites in Island Southeast Asia. The cave known to local people as Lené Hara (also Lené Ara) is an internationally significant site, based on its scientific values. It is not only one of the oldest occupation sites in Island Southeast Asia, but it also houses a considerable display of rock art, including painted art and the recently discovered petroglyphs described above (O'Connor et al. 2010b). Lené Hara is highly significant to Fataluku people, being identified as the next 'settlement' occupied after the ancestors of Tutuala Ratu left the site known as Ili Kérékéré. It is also a resource zone where young men come to collect bird's nest which they sell to Chinese traders in the nearby town of Los Palos.

Lené Hara cave also has historical significance as a narrative space on changing colonial and post-colonial research perspectives. In the early 1960s, the Portuguese archaeologist, Almeida, excavated two trenches and described some of the art. The resulting brief publication on the excavation focuses on the stone artefacts and draws comparisons with European artefact 'types' (Almeida and Zbyszewski 1967). In the late 1960s, Lené Hara was visited by Ian Glover and John Mulvaney from The Australian National University. Glover's assessment of the pottery and stone artefacts drew comparisons with the archaeology of other sites in Timor-Leste and the broader Southeast Asian region, rather than with Europe (Glover 1972 (1):40-1, (2): plate 3.2; Glover 1986:7). Glover also described and photographed 'an interesting structure, a forked wooden pole set in a low semi-circle of stones, reminiscent of the spirit shrines of central Timor' (Glover 1986:17). The structure he described is the Lené Hara téi (Figure 11). This large stone platform is built against a massive speleothem column. It has a prominent upright stone marking the téi centre. As well as the téi, Lené Hara is divided by an extensive length of stone walling, which includes a gateway with standing stones. None of these features were noted by Almeida and yet they must have been just as prominent at the time of his excavation in the early 1960s as they were when Glover visited a few years later, and as they are today. Almeida's excavation was carried out as part of an official Portuguese government 'mission'. It would appear that, as a result, no permissions were sought from the landowning ratu, no ceremonies were undertaken by the 'lord of the land' prior to or following the excavations, and all vestiges of Fataluku customary ownership were regarded as unworthy of documentation.

O'Connor, Spriggs and Veth undertook excavations at Lené Hara in 2000 and, in association with Pannell, again in 2002 (O'Connor et al. 2002; 2010a). In 2000, the excavations were undertaken under the direction of the state appointed head of Tutuala, the kepala desa (Indonesian, chefe de suco, Tetum). ${ }^{3}$ At the time, the 'lord of the land' for Tutuala ratu was consulted about the

3 The excavation took place prior to the establishment of Portuguese and Tetum as the official languages of Timor-Leste. 
excavation and he gave his permission and a local field team was subsequently employed. No ceremony was performed at the Lené Hara téi as we were unaware that any was required. Towards the end of the excavation we were approached by a group of angry young men. We asked our Fataluku-speaking translator what the problem was and she informed us that this group of men were in fact the close relatives of the 'lord of the land', who wanted to know why they had not been given work with us. Unbeknown to us, the field crew we had employed was entirely selected from the family and associates of the kepala desa. Thus, our team had represented the state, as much as the kepala desa and his associates represented this entity, but it did not necessarily represent the community of people with customary rights to the site.

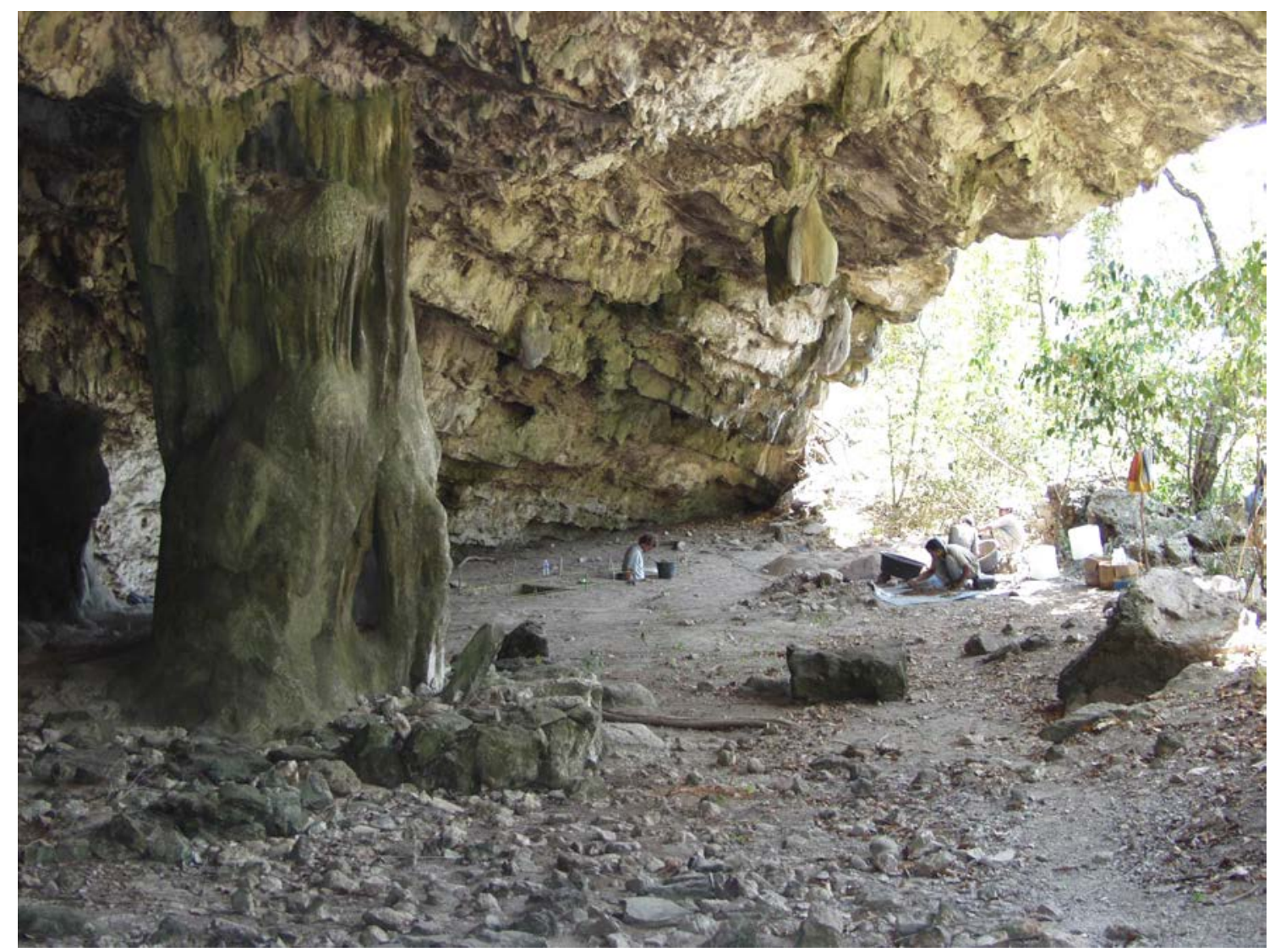

Figure 11. Lené Hara cave showing the speleothem with the téi platform during the excavations in 2002.

Source: Sue 0'Connor.

The 2002 field season involved the excavation of three test pits in different parts of the Lené Hara cave. In this year, the team, consisting of two archaeologists and an anthropologist (respectively, O'Connor, Veth and Pannell), was careful to ensure that our community-based consultations were more inclusive. The local field crew was chosen by the 'lord or the land' and by senior members of Tutuala ratu, in consultation with the chefe de suco. The appropriate rituals were carried out at the téi prior to and following the excavations. The rituals were performed to accompany the 'opening' and the 'closing' of the earth and they involved the sacrifice of a pig, and offerings of lontar spirit and rice to the Lené Hara téi. This was considered necessary to ensure the safety of all those involved in the excavation, as well as the safety of their respective families. In one of the excavation pits, Pit D, a human cranium was uncovered (O'Connor et al. 2010b). The cranium was not exhumed. After consultation with the 'lord of the land' and other landowners, the pit was backfilled with the cranium in situ (O'Connor and Pannell 2006:40-41; O'Connor et al. 2010a). 
Despite our efforts, when we returned in 2003 we were told that some Fataluku people blamed the excavations at Lené Hara, specifically the exposure of human skeletal remains, for the death of the 'lord of the land' earlier in the year.

What transpired at Lené Hara over the course of two field seasons aptly demonstrates the complexity of carrying out research or heritage assessment, and the porosity of the concepts of nature and culture, in this part of Timor-Leste. It is clearly a cave of natural origin, yet it is conceptualised as a settlement or village by Fataluku people (and by archaeologists as well, who regard it as a site of previous human occupation), it is also seen as part of a wider resource zone, along with other nearby caves, where young men come to collect birds' nests, and it is a téi place, and thus acknowledged as a powerful and potentially dangerous locale.

According to our research findings, another rockshelter in the area known as Jerimalai was first occupied more than 42,000 years ago (O'Connor 2007). It is the oldest modern human settlement site in Island Southeast Asia, east of the Sunda Shelf, and it is unique on a world scale due to its abundant evidence of maritime resource exploitation. Jerimalai contains the world's earliest evidence for systematic pelagic fishing and the manufacture of fish hooks (O'Connor $e t$ al. 2011b). The assemblage was also very rich in shell decorative artefacts, including shell beads and pendants made of several different species. This shelter does not have the same level of significance to Fataluku people as Lené Hara, as it is not central to local origin myths and nor is it empowered by a non-human presence. But like the many other shelters in the area, it is used by men while on hunting expeditions in the secondary forest surrounding it. Jerimalai contains abundant evidence of contemporary use, such as fragments of metal plates, coconut bowls, recent hearths, and wooden racks for cooking game (O'Connor and Pannell 2006:21; O'Connor 2007).

The caves identified as Matja Kuru 1 and 2 similarly have abundant evidence of human use from ancient times through to today. The finds in the excavated assemblages indicate that periodically the caves served as base-camps for people exploiting a wide variety of resources from the surrounding area. These include long neck turtle from the freshwater lake to the south, monkeys and cuscus from the forests between the lake and the coast, as well as fish and shellfish from the coast over eight $\mathrm{km}$ to the north (Spriggs et al. 2003; Veth et al. 2005; O'Connor 2006, 2010). Like Jerimalai, the Matja Kuru caves also contained abundant evidence of contemporary Fataluku use, including a pottery still for making palm spirit, and the remains of hearths and racks, used by hunters pursuing game in the forest (Pannell and O'Connor 2005).

\section{Walled settlements}

A number of old stone fortified settlements have been located within the Park. Fataluku oral traditions, as well as the physical features of the settlements, indicate that they were primarily built for defence purposes. These features include the massive nature of the walls themselves, the fact that the walls encircle and enclose the settlements and ritual areas inside, the very narrow entrances, and their location on bluffs and/or cliff top edges with clear views to the coast and often sheer precipitous drops off one or more sides (Figure 12). Inside the fortified walls are raised stone platforms, which are often over a metre high and rectangular in form. They are said to be the graves of ancestors (calu lutur or narunu) (Figure 13). Other areas inside the fortified sites are identified as circumscribed spaces called sépu, where ceremonies and dances were performed (Lape 2006; O'Connor et al. 2012). Site maps produced for two of these settlements, Locami (Lo Chami) and Lori Lata, show some of these features (Lape 2006). 


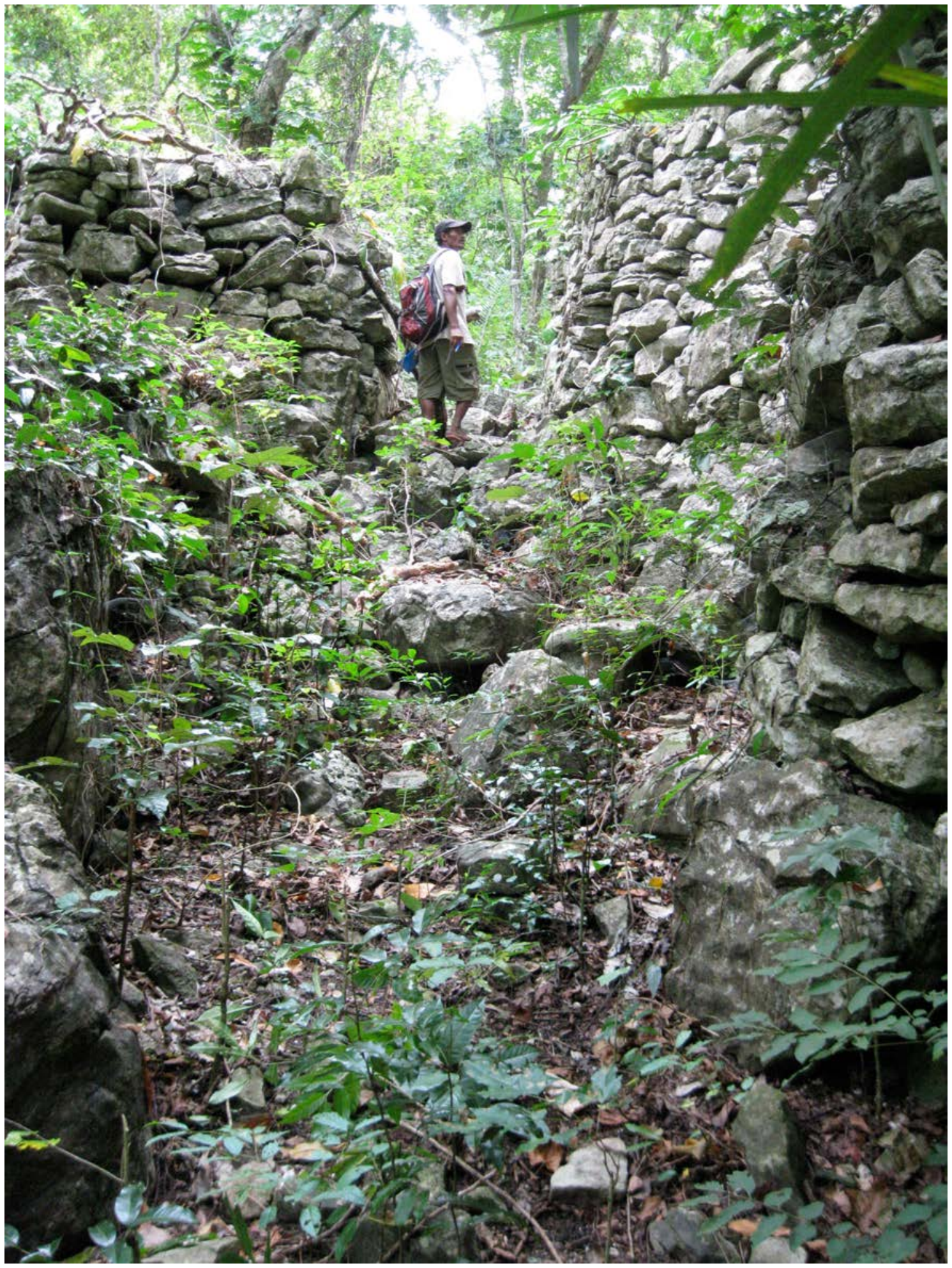

Figure 12. Massive walls surrounding a fortified settlement in within the forested region of Nino Konis National Park.

Source: Sue 0'Connor.

Several such sites in the Tutuala and Com areas have been test-pitted and their occupation dated. These include Tutuala, Lori Lata, Lopomalai, Ili Mimiraka, Mua Mimiraka, and Tutun (Tutunca'u) near Tutuala and Macapainara near Com. Results of radiocarbon dating on marine shell and charcoal and OSL dating of pottery from the sites suggest that the fortified structures began to be 
constructed after 1300 AD (Lape 2006; O'Connor et al. 2012). They appear to have continued to be made and used into the historic period, and some were still in use up until the middle of the 20th century (O'Connor et al. 2012; O'Connor and Pannell 2006:25; Pannell 2006b). As previously indicated, while these ancestral settlements are no longer permanently occupied, ratu members regularly return to them to perform rituals and ceremonies at the téi and grave sites located within them (O'Connor and Pannell 2006:37). Even Jaco Island (Totina), which is said to have no permanent sources of freshwater, has at least two large fortified village sites.

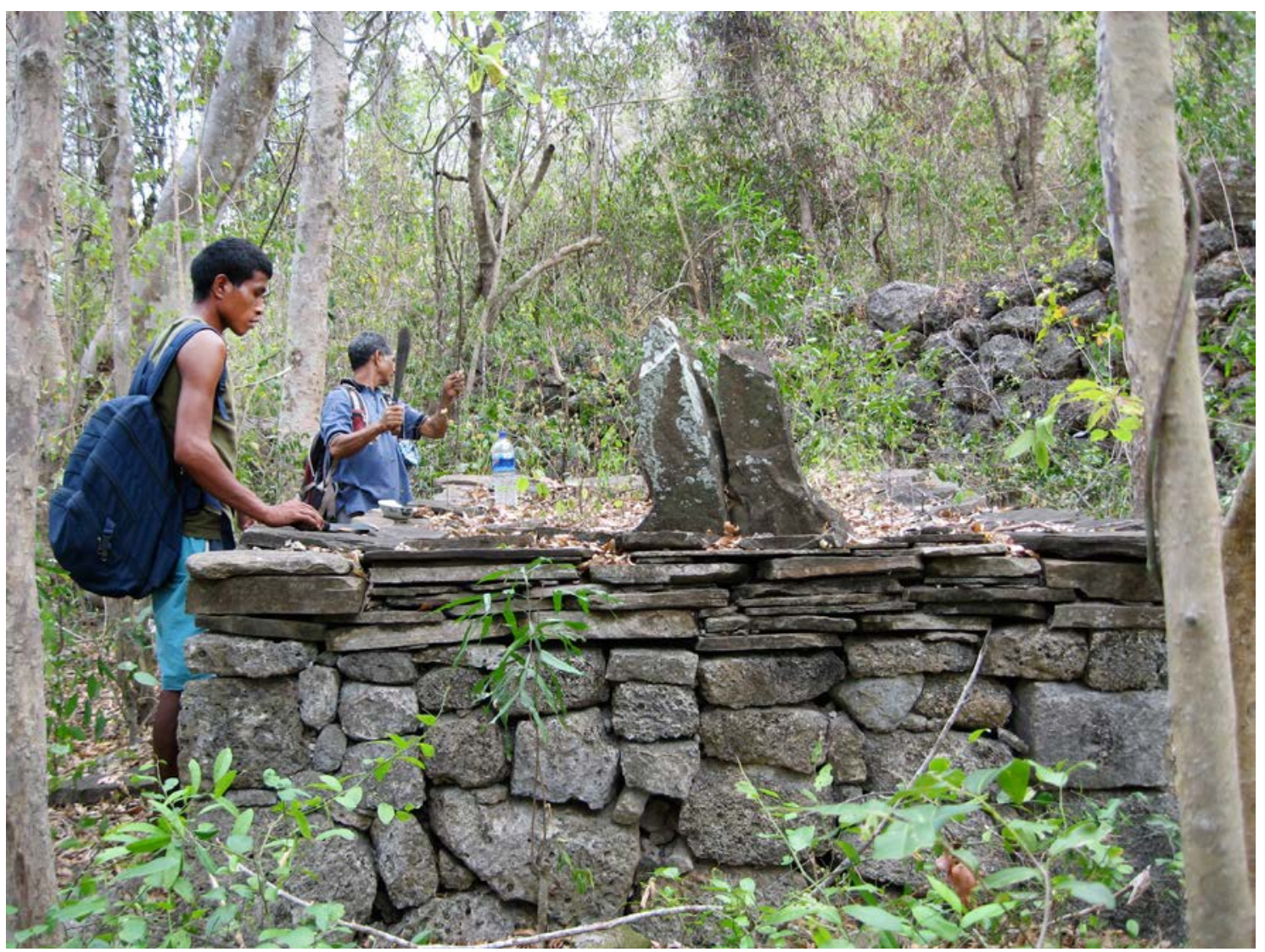

Figure 13. Monumental ancestral grave at the fortified settlement of Macapainara near Com.

Source: Sue $0^{\prime}$ Connor.

The forest survey undertaken by McWilliam and O'Connor in 2009 located many more stone walled fortified settlements in the remote, densely forested areas of the Park, including Mapulo, the ancestral village of Nino Konis Santana himself (Figure 14). The forest floors throughout this part of the Park are criss-crossed with stone walling bearing witness to the density of past human occupation of this region.

\section{Scatters of stone artefacts, pottery sherds and shell}

Scatters of stone artefacts (nelukala), pottery sherds and shell are commonly found surrounding resource areas, such as those adjacent to freshwater springs located in the limestone terraces and at the back of coastal embayments and beaches. It is difficult to ascertain whether these scatters represent the remains of community activities at a particular point in time or whether they are palimpsests representing thousands of years of episodic human visitation. While these sites are recognised by local people as resulting from human activities, they are not of themselves considered to hold 'cultural' significance. However, they often co-occur with important cultural sites and ceremonial aggregation areas, such as at water sources, ancestral settlement sites, and at téi sites. 


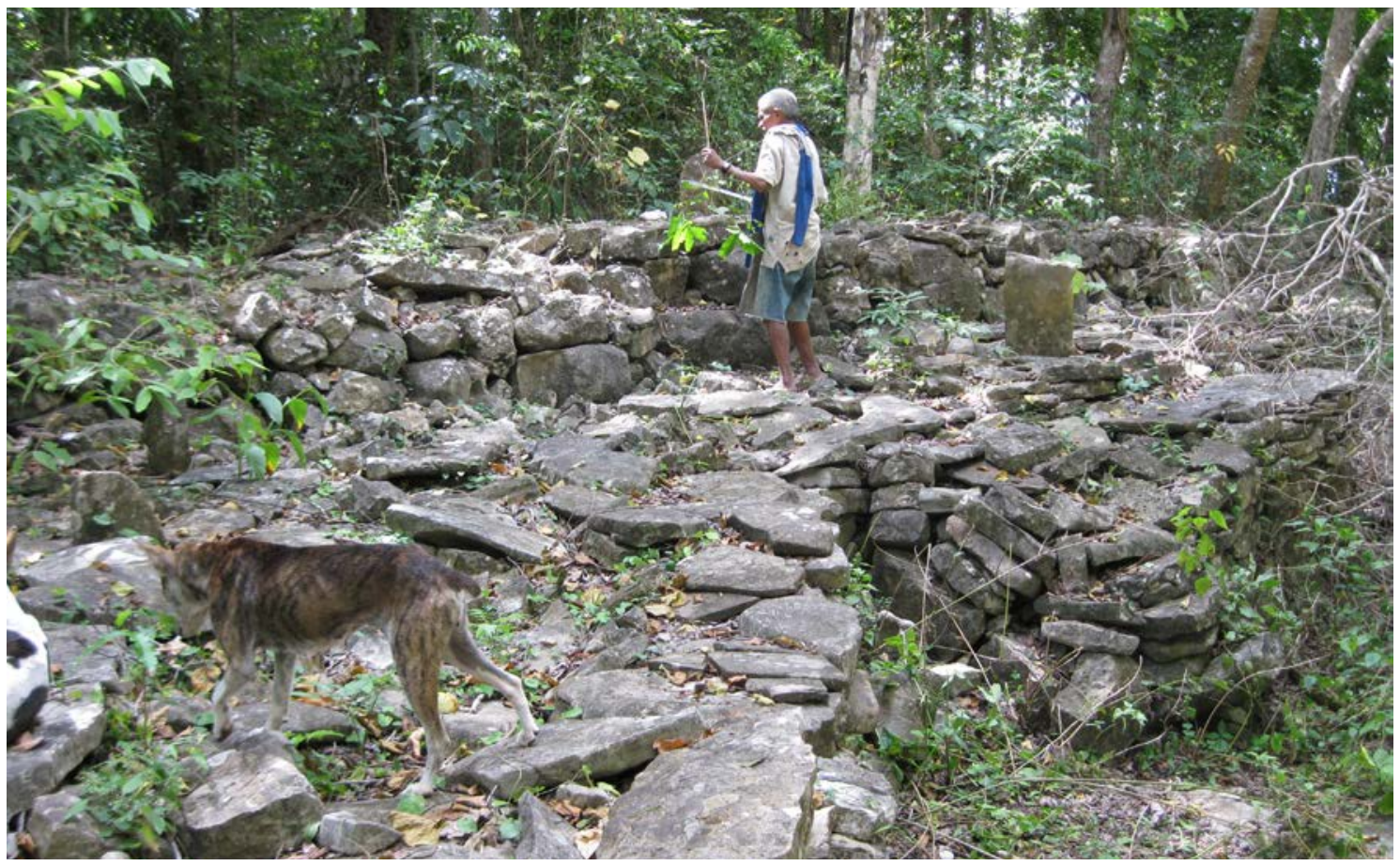

Figure 14. Ancesestral graves and internal walling at Mapulo the ancestral village of the Falantil commander Nino Konis Santana. Vardemar Cabral, a relative of Nino Konis Santana, is clearing weeds from around the graves.

Source: Sue 0'Connor.

The open area at the back of Valu Beach provides a good example of this kind of tangible and intangible symbolic nexus. It contains a sparse scatter of pottery, stone artefacts and shell, as well as broken and abandoned contemporary artefacts, such as cigarette lighters, thongs and broken floats. Today this back beach zone is used by the fisherman servicing the tourists who come to camp, swim and snorkel on the weekends. We were told that during the historic period families would bring their goods to trade here during specific times of the year when people from the island of Leti and other islands to the east came to exchange pottery, goats and other goods, such as corn. The shallow overhangs and back beach area on Jaco Island, which face Valu Beach, are said to have been delegated by the 'lord of the land' to the incoming traders from Leti, and thus this area is known as Leti Mo. The Valu Beach site was excavated in 2004 with the assistance of Abilio da Silva (from the Ministry of Education) (Figure 15). Consistent with Fataluku oral traditions, it has pottery sherds dated between $1800 \mathrm{BP}$ and the present (O'Connor and Pannell 2006:22-23).

\section{Burial sites}

Prior to the resettlement of the local population at roadside locations, the deceased were buried within the walled compound of former settlements. In these settlements, graves (narunu or calu lutur) are marked by a rectangular platform of layered stones (O'Connor et al. 2012). Former settlements contain the graves of unknown distant ancestors, as well as more recently deceased, known individuals (O'Connor and Pannell 2006:40). At the ancestral settlement complex of Nari, located between Com and Los Palos, current senior ratu members have recorded a long genealogy of named individuals for the ancestral graves However, the more distant of these are considered $l u l i k^{4}$ or 'taboo' and their names are thus not to be spoken.

4 Lulik (Tetum but also used as a generic term in other languages in Timor-Leste. Lulik has usually been translated as 'sacred' or 'taboo' (Hull 2002:227, Hicks 2004:25). Bovensiepen (2011:47-8) states that amongst Idaté speakers, lulik is used as an adjective, noun and 


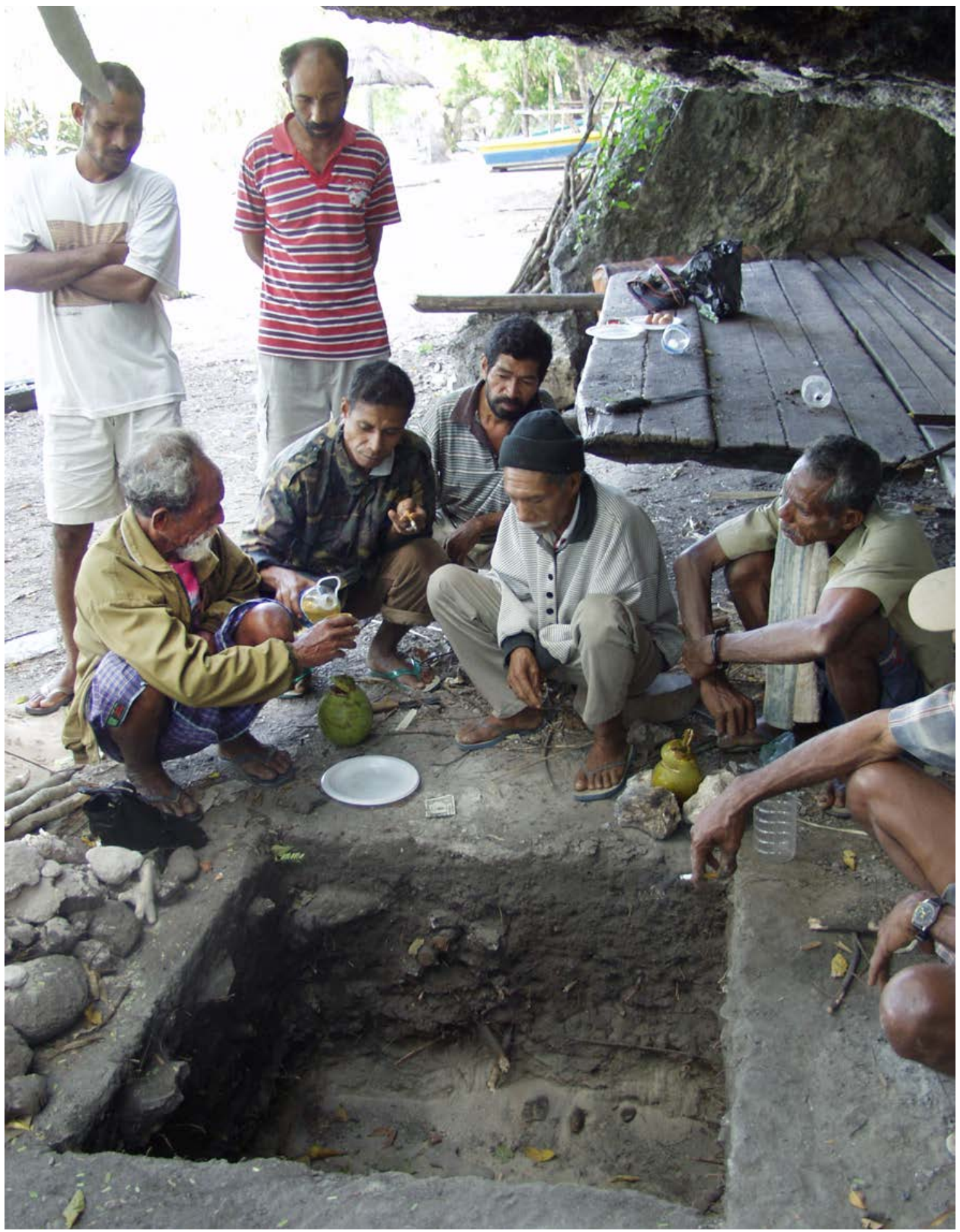

Figure 15. Senior ratu members conduct closing ceremony following the excavation at Valu Beach site in 2004.

Source: Sue 0'Connor.

Most burial sites consist of large raised rectangular stone structures, sometimes marked with status goods, such as buffalo horns or ceramic bowls or plates of Chinese or European origin (Figure 13), but some burial caves are also known. A burial cave recorded in an area of forest

verb and 'can designate an avoidance relationship, but also refers to a potent source of power, prosperity and danger, usually associated with the land and the ancestors'. 
within the Park, south of the settlement of Méhara, contained remains of secondary burials and an eggshell blue celadon ceramic bowl. In more recent (but no longer permanently occupied) open settlements, graves are marked by concrete structures, which are sometime decorated with traditional motifs (known as lakulili), and they are generally located on the edge of the residential area. Here again we see the porosity of nature and culture. As noted above, one of the most commonly occurring motifs in the rock art of the region is known as poko. These motifs are not regarded as a product of human agency but rather they are said to have been come into being following the creation of the land itself and thus have strong ritual connections for ratu members and they are sometimes reproduced on the graves of ratu members.

In Méhara, the graves of a number of people killed during the Indonesian occupation are also located within the household compound. In the Tutuala region, the graves of a number of prominent, named Fataluku antecedents and ancestral figures featured in local origin narratives are located outside of settlement complexes. On Jaco Island, we also recorded a massacre site dating from 1984. According to Fataluku informants, Indonesian forces killed six local people, and threw their bodies into a sinkhole in the karst limestone. While some of the skeletal remains of these murdered individuals were still present in October 2002, the remains of four of the murdered individuals had been removed by family members just prior to this date.

\section{Water sources}

In the Tutuala region, we recorded current and previously used, but now dry, water (ira) sources known to informants. In this area, water sources include; permanent springs (ira ina), emerging at around an altitude of $300 \mathrm{~m}$ in the uplifted limestone terraces; a number of spring-fed sources along the coast only accessible at low tide; seasonal rockholes (piar ira) (often protected with a rock lid); ephemeral creeks and rivers (wéru); temporary rain-filled depressions (luri), and drip seepage (сирисири) and drip-fed pools in caves (O'Connor and Pannell 2006:38).

In Com and in areas surrounding Tutuala drinking water is obtained from several springs located on the raised limestone terraces behind the village. Using an elaborate system of channels, water from these springs is used to irrigate nearby crops and supply water to households now settled along the coast road leading to the harbour at Com. In Méhara, drinking water is obtained from a number of localised springs and, when lake levels permit, from nearby Lake Iralaloro. The hamlet of Malahara obtains its drinking water from the lake outlet before it goes underground and resurfaces in the sea (tahi calu) near Loré on the south coast. In the Com, Méhara, and Tutuala regions, permanent water sources have mythological and ritual significance. For example, the discovery of permanent spring-fed water is often attributed to a dog (iparu) in local origin narratives. The water sources associated with these accounts are often marked with téi structures (O'Connor and Pannell 2006:39). Reflecting their téi status, as places associated with a range of ritual and ceremonies restrictions and responsibilities, permanent springs are often fenced or walled off, not only protecting the téi related values of the sites, but also the water itself from contamination by animals. At the ancestral settlement complex of Nari we recorded an elaborate walled well. This water feature is marked by a téi and it is part of a stone arrangement which is said to be a symbolic representation of the ancestral ratu structure for this area (Figure 16). In a landscape and a country in which water availability is naturally restricted and many people regularly experience water shortages in the dry season months, one could argue that the identification of water sources as téi places, associated with mythological events, affords a form of protection which is far more intelligible to local people than an IUCN protected area category or national legislation. In a similar manner, as McWilliam has documented, the local designation of forested groves as 'lulik' or 'sacred' in other parts of the island has certainly contributed to their preservation over the years (McWilliam 2011). 


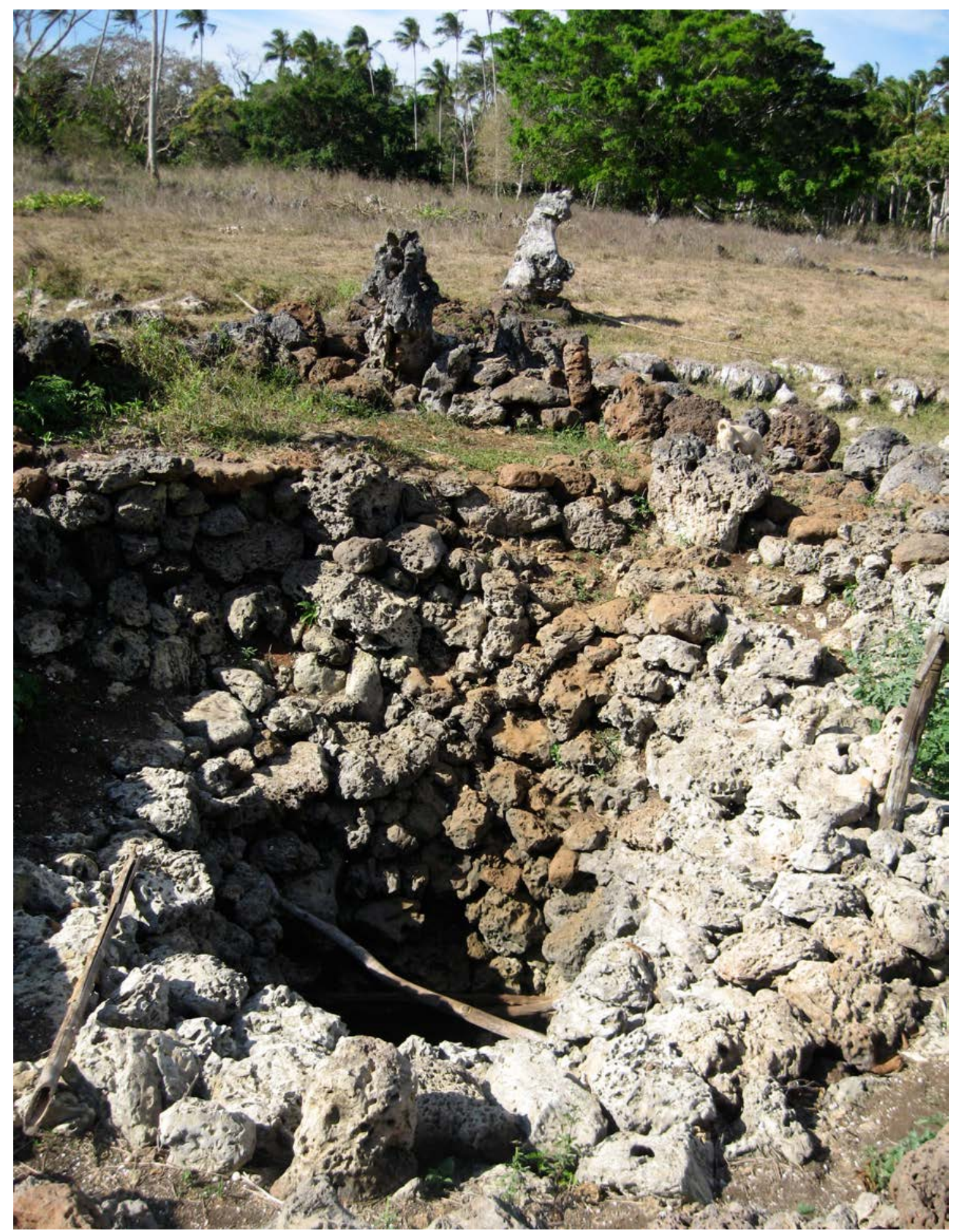

Figure 16. Lulira at the settlement of Nari is both a water site and an ancestral ritual site. It includes a deep stone walled well and elaborate stone arrangements which include a téi, téi Mauresi and a stone arrangement that symbolises the structure of the ancestral ratu. Kati ratu is said to be shown at the centre of the arrangement. 


\section{Discussion}

From a conservation perspective, the Nino Konis Santana National Park should be regarded as an anthropogenic landscape. As we have discussed at length, much, if not all, of the forested areas of the Park have been altered and shaped by thousands of years of human occupation and use. With very few exceptions, this is the situation found throughout Timor-Leste (see for example, Metzner 1977 for the Baucau and Viqueque areas). The identification of the Park as a 'Category V' 'Protected Landscape/Seascape' theoretically makes it possible to recognise this human-environment interaction and its long history. Under UNESCO provisions, Category $\mathrm{V}$ protected 'landscapes/seascapes' provide for the preservation of lifestyles and support for customary economic activities. That said, many Fataluku traditional subsistence activities have been banned or curtailed by the regulations governing Park use. The current restrictions on hunting will certainly adversely affect the kind of subsistence flexibility that has enabled local people to deal with chronic environmental uncertainty for thousands of years and more recent acute political instability (Pannell 2011). The limits on hunting will also reduce the regularity with which Fataluku people are able to visit the more remote areas of the Park in order to maintain their ancestral connections and ritual responsibilities.

Since Independence, Timor-Leste has witnessed a resurgence in customary law, beliefs and ritual. For example, despite the impoverished circumstances that most communities currently live in, scarce resources are being directed towards the construction of new 'ancestral' houses, which were destroyed during the period of Indonesian governance, and 'pagan' rituals that were once banned, are now being revitalised. In many respects, this resurgence is at odds with the attempts made by the Timor-Leste national governments to impose 'cultural uniformity' on the social fabric of life and their efforts to impress public good models on the land and resources of the Park. In order for the Park to be a 'success' it will need to be viewed by Fataluku people as their Park. It is hoped that local ratu involvement will become a central part of future negotiations, zoning decisions and management models.

In this regard, there is some evidence that the national government is serious about acknowledging local people and local beliefs in the management of natural resources and environment. For example, as part of the 'Regional Fisheries Livelihood Program for South and Southeast Asia' (RFLP), sponsored by the Spanish Government and the United Nations Food and Agriculture Organization, fishing communities in Timor-Leste are being encouraged to document 'traditional laws', known as 'tara bandu'. According to a recent RFLP newsletter, the laws and customs identified as 'tara bandu' function to 'restrict access to and use of natural resources and spaces and as such constitute a traditional resource protection and management mechanism' (RFLP 2012:1). Communities are being encouraged to submit written versions of their 'traditional laws' to the national authorities, which are apparently 'seeking to recognise the usage and enforcement of traditional laws' in the management of coastal resources (RFLP 2012:1). Local people's familiarity with their own laws and customs is identified by RFLP officers as one of the ways to overcome the problems associated with local compliance with national fisheries legislation (RFLP 2012). While this may be the case, government acknowledgement of local communities as the traditional owners of natural resources and environments, is also one way to counter the unregulated use of resources and areas. Ironically, protected area zoning which 'locks up' 'wilderness' and 'locks out' the traditional custodians, opens the floodgates to illegal timber cutters and other resource raiders. In the case of the Nino Konis Santana National Park, the restriction of Fataluku people's traditional occupation and use of the Park, coupled with the near absence of enforcement agents, in the form of Park rangers, has all the potential to create yet another 'tragedy of the commons' (Hardin 1968). 
While the RFLP initiative can be regarded as a significant step towards community-based resource management, the written codification of local belief systems and related social behavior, and reliance upon national or local government systems to acknowledge and foster these traditional practices, raises a number of issues in its own right. One is reminded here of the discussion which took place in the 1990s regarding the concept of 'sasi', identified in the literature as a Moluccanbased 'marine resource management institution' (see Bailey and Zerner 1992). In this regard, Pannell's comments regarding 'sasi' equally apply to the RFLP initiative involving 'tara bandu':

Our understanding of sasi is further obstructed if we impute to it a set of values, a range of functions or an efficacy which are neither apparent or intended ... There are inherent problems of translation when we attempt to read Indigenous practices and knowledges in terms of the discourses of non-Indigenous environmental management approaches. (Pannell 1997:292)

As Pannell points out, and following Aboriginal examples from northeast Arnhem Land and Cape York Peninsula, perhaps what is needed is a reformation of the fundamental tenets and orientation of current environmental and resource management strategies, what Donald Brenneis calls a 'new conception of rights' (2003:219). We suggest here that a different approach may have as its focus the recognition of cultural values and social practices as the primary means of ensuring some forms of biological diversity and ecotopic integrity. In this approach, Indigenous expressions of what their culture is and how it should be maintained, their rights relating to the ownership and use of lands and seas, natural resources, cultural property and local knowledge, and their interests in economic development and political recognition would constitute the basis for the criteria and intentions of management (Pannell 1997:302-303). In the case of the Nino Konis Santana National Park, with careful planning, the cultural resources of the Park hold enormous potential to provide sustainable livelihoods for the Fataluku communities who live within its boundaries. In the meantime, however, in the far eastern reaches of Timor-Leste, government inaction has provided local people with some respite from the discourse and dictates of nature-based protected area management.

\section{Postscript}

As of March 2012 there has still been no formal zoning for the Park and no initiatives have been implemented for managing, protecting or interpreting the rock art and other cultural sites within the Park. Valu Beach continues to attract regular tourists from Dili, who stay at the eco resort. These tourists come predominantly to swim and snorkel on the coral fringed beaches of Valu and Jaco Island. Some also go to explore the caves and rock art sites of Lené Hara and Ili Kérékéré. Currently, there is no Park-based system to manage tourist visits to these cultural sites or to ensure that visitors are guided by the appropriate land owners. No information on the rock art or the cultural values of the Park is available as signage or literature or on the MAF's website. The few Park Guards employed by Protected Areas within MAF have received some training on the natural heritage values of the Park and the MAF regulations and measures designed to protect it, but none on the cultural heritage values of the Park. No wide-scale community consultation has been undertaken and no attempt has been made at mapping the contemporary cultural values and ancestral ties of the different ratu groups living within the Park.

\section{Acknowledgements}

The research for this paper was supported by an Australian Research Council Discovery Grant to O'Connor (DP0556210), to O'Connor and McWilliam (DP0878543) and a Linkage Grant to O'Connor and Byrne (LP0776789). The Australian National University and the Rainforest 
Cooperative Research Centre, James Cook University are also thanked for research support to O'Connor, Brockwell and Pannell. Peter Lape is thanked for his involvement in the field during the rock art recording. In Timor-Leste we extend our thanks and appreciation to staff of the Ministry of Education and the Ministry of Agriculture and Fisheries, who assisted us during our surveys. Permissions for the archaeological excavations, rock art recording and surveys were obtained from the Ministry of Education and Culture. We would particularly like to thank $\mathrm{Sr}$ Virgílio Simith, Sra Cecília Assis and Sr Abilio da Silva for facilitating this process. We also wish to acknowledge the support of the Director of Protected Areas and National Parks, National Directorate of Forestry in the Ministry of Agriculture and Fisheries, Manuel Mendes, who gave permission for O'Connor, McWilliam and Aplin to work within the Nino Konis Santana National Park following its formal declaration in 2008. We would particularly like to acknowledge the support of the people of Tutuala, Com and Méhara, without whom this research would not have been possible.

\section{References}

Almeida, A. De and Zbyszewski, G. 1967. A contribution to the study of the prehistory of Portuguese Timor-lithic industries. In: Solheim II, W.G. (ed.), Archaeology at the Eleventh Pacific Science Congress: Papers presented at the XI Pacific Science Congress, Tokyo, August-September 1966, pp. 55-67. Asian and Pacific Archaeology Series, Honolulu.

Bailey, C. and Zerner, C. 1992. Community-based fisheries management institutions in Indonesia. Maritime Anthropological Studies 5(1):1-17.

Bovensiepen, J. 2011. Opening and closing the land: Land and power in the Idaté highlands. In: McWilliam, A. and Traube, E. (eds), Land and life in Timor-Leste: Ethnographic essays, pp. 47-60. ANU E-Press, Canberra.

Brenneis, D. 2003. Toward new conceptions of rights. In: Zerner, C. (ed.), Culture and the question of rights: Forests, coasts, and seas in Southeast Asia, pp. 212-235. Duke University Press, Durham.

Collins, S., Martins, X., Mitchell, A., Teshome, A. and Arnason, T. 2007. Fataluku medicinal ethnobotony and the East Timorese military resistance. Journal of Ethnobotany and Ethnomedicine 3(5) Published online Jan 22. 2007.

Edyvane, K., Cavalho, N., Penny, S., Fernandes, A., de Cunha, C.B., Amaral, A.L., Mendes, M and Pinto, P. 2009a. Conservation values, issues and planning in the Nino Konis Santana Marine Park, Timor Leste - final report. Ministry of Agriculture and Fisheries, Government of Timor Leste, Dili.

Edyvane, K., McWilliam, A., Quintas, J., Turner, A., Penny, S., Texeira, I., Pereira, C., Tibirica, Y. and Birtles, A. 2009b. Coastal and marine ecotourism values, issues and opportunities on the north coast of Timor Leste - Final Report. Ministry of Agriculture and Fisheries, National Directorate of Tourism, Government of Timor Leste, Dili.

Glover, I. 1972. Excavations in Timor: A study of economic change and cultural continuity in Prehistory. Unpublished $\mathrm{PhD}$ thesis. Australian National University.

Glover, I. 1986. Archaeology in Eastern Timor, 1966-67. Australian National University, Canberra.

Hardin, G. 1968. The tragedy of the commons. Sciences 162:1243-1250.

Hicks, D. 2004. Tetum ghosts and kin: Fertility and gender in East Timor (2nd edition), Waveland, Long Grove.

Hull, G. 2002. Standard Tetum-English dictionary, (3rd edition), Sebastiao Aparicio da Silva Project in Association with Insituto Nacional de Linguistica, Timor Leste. Winston Hills. 
IUCN. 1994. Guidelines for protected area management categories. IUCN, Gland.

Katz, C. 1998. Whose nature, whose culture? Private productions of space and the 'preservation' of nature. In: Braun, B. and Castree, N. (eds), Remaking reality: nature at the millenium, pp. 46-64. Routledge, London.

Lape, P. 2006. Chronology of fortified settlements in East Timor. Journal of Island and Coastal Archaeology 1(2):285-97.

Lape, P.V., O'Connor, S. and Burningham, N. 2007. Rock art: A potential source of information about past maritime technology in the Southeast Asia-Pacific region. The International Journal of Nautical Archaeology 36 (2):238-53.

Luke, T.W. 1995. The nature conservancy or the nature cemetery: Buying and selling 'perpetual care' as environmental resistance. Capitalism Nature Socialism 6:1-20.

McKinnon, S. 1991. From a shattered sun: Hierarchy, alliance and exchange in the Tanimbar Islands. University of Wisconsin Press, Wisconsin.

McWilliam, A. 2006. Fataluku forest tenures in the Conis Santana National Park in East Timor. In Reuter, T. (ed.), Sharing the earth; Dividing the land: Land and territory in the Austronesian World, land tenure in the Austronesian World, pp. 253-76. ANU E-Press, Canberra.

McWilliam, A. 2007a. Customary claims and the public interest: Fataluku resource entitlements in Lautem. In: Kingsbury, D. and Leach, M. (eds), East Timor: Beyond independence, pp. 165-78. Monash Asia Institute Press, Melbourne.

McWilliam, A. 2007b. Austronesians in linguistic disguise: Fataluku cultural fusion in East Timor. Journal ofSoutheast Asian Studies 38:355-75.

McWilliam, A. 2011. Fataluku living landscapes. In: McWilliam, A. and Traube, E. (eds), Land and life in Timor-Leste, ethnographic essays, pp. 61-87. ANU E Press, Canberra.

Mau, R. 2010. Ecosystem and community based model for zonation in Nino Konis Santana National Park, Timor-Leste. Unpublished MS thesis. Bogor Agricultural University.

Metzner, J. 1977. Man and environment in Eastern Timor: A geo-ecological analysis of the Baucau-Viqueque area as a possible basis for regional planning. Monograph No. 8, Development Studies Centre, Australian National University, Canberra.

O'Connor, S. 2003. Nine new painted rock art sites from East Timor in the context of the Western Pacific region. Asian Perspectives 42:96-128.

O'Connor, S. 2006. Unpacking the island Southeast Asian Neolithic cultural package, and finding local complexity. In: Bacus, E.A., Glover, I.C. and Pigott, V.C. (eds), Uncovering Southeast Asia's Past, pp. 74-87. Singapore: NUS Press.

O'Connor, S. 2007. New evidence from East Timor contributes to our understanding of earliest modern human colonization east of the Sunda Shelf. Antiquity 81:523-35.

O'Connor, S. 2010. Continuity in shell artefact production in Holocene East Timor. In Bellina, B., Bacus, E.A., Pryce, T.O. and Wisseman Christie, J. (eds), 50 years of archaeology in Southeast Asia: Essays in honour of Ian Glover, pp. 218-33. Rivers Books, Bangkok.

O'Connor, S. and Aplin, K.P. 2007. A Matter of balance: An overview of Pleistocene occupation history and the impact of the Last Glacial Phase in East Timor and the Aru Islands, eastern Indonesia. Archaeology in Oceania 42 (3):82-90.

O'Connor, S. and Oliveira, N.V. 2007. Inter and intra regional variation in the Austronesian painting tradition: A view from East Timor. Asian Perspectives 46 (2):389-403. 
O'Connor, S. and Pannell, S. 2006. Cultural heritage in the Nino Conis Santana National Park: A preliminary survey. Unpublished report prepared for the Department of Environment and Conservation, New South Wales.

O'Connor, S., and Veth, P. 2005. Early Holocene Trochus shell fish-hooks from East Timor. Antiquity 79:1-8.

O'Connor, S., Spriggs, M. and Veth, P. 2002. Excavation at Lené Hara establishes occupation in East Timor at least 30,000-35,000 years on: Results of recent fieldwork. Antiquity 76:45-50.

O’Connor, S., Barham, A., Spriggs, M., Veth, P., Aplin, K. and St. Pierre, E. 2010a. Cave archaeology and sampling issues in the tropics: A case study from Lené Hara Cave, a 42,000 year old occupation site in East Timor, island Southeast Asia. Australian Archaeology 71:29-40.

O'Connor, S., Aplin, K., St. Pierre, E. and Feng, X. 2010b. Faces of the ancestors revealed: Discovery and dating of Pleistocene-aged petroglyphs in Lené Hara Cave, East Timor. Antiquity 84 (325):64965.

O'Connor, S., Pannell, S. and Brockwell, S. 2011a. Whose culture and heritage for whom? Exploring the limitations of National Public Good Protected Area Models in East Timor. In: Miksic, J., Goh, G. and O'Connor, S. (eds.), Rethinking cultural resource management in Southeast Asia: Preservation, development and neglect, pp.39-66. Anthem Press, London.

O’Connor, S., Ono, R. and Clarkson, C. 2011b. Pelagic fishing at 42,000 BP and the maritime skills of modern humans. Science 334:1117-21.

O'Connor, S., McWilliam, A., Fenner, J.N. and Brockwell, S. 2012. Examining the origin of fortifications in East Timor: Social and environmental factors. Journal of Island and Coastal Archaeology 7:200-18.

Palmer, L. and do Amaral de Carvalho, D. 2008. Nation building and resource management: The politics of 'nature' in Timor Leste. Geoforum 39:1321-32.

Pannell, S. 1997. Managing the discourse of resource management. The case of sasi from 'southeast' Maluku, Indonesia. Oceania 67:289-307.

Pannell, S. 2006a. Reconciling nature and culture in a global context: Lessons from the World Heritage List. Rainforest CRC, Cairns.

Pannell, S. 2006b. Welcome to the Hotel Tutuala: Fataluku accounts of going places in an immobile world. Special Edition, The Asia Pacific Journal of Anthropology 7(3):203-21.

Pannell, S. 2011. Struggling geographies: Rethinking livelihood and locality in Timor-Leste. In: McWilliam, A. and Traube, E. (eds), Land and life in Timor-Leste, ethnographic essays, pp.217-39. ANU E Press, Canberra.

Pannell, S. and O'Connor, S. 2005. Toward a cultural topography of cave use in East Timor: A preliminary study. Asian Perspectives 44(1):193-206.

Pannell, S. and O'Connor, S. 2010. Strategy blurring: Flexible approaches to subsistence in East Timor. In: Hardy, K. (ed.), Archaeological invisibility and forgotten knowledge, pp. 115-30. British Archaeological Reports BAR International Series, Archaeopress, Oxford.

Pannell, S. and O'Connor, S. 2013. Where the wild things are: An exploration of sacrality, danger and violence in confined spaces. In: Moyes, H. (ed.), Journeys into the dark zone: A cross cultural perspective on caves as sacred spaces, pp. 317-30 University of Colorado Press, Boulder.

RFLP. 2012. Regional fisheries livelihood program in South and Southeast Asia E-newsletter, February 2012.

Schama, S. 1995. Landscape and memory, Knopf, New York. 
Schapper, A. 2012. Finding Bunaq: The homeland and expansion of the Bunaq in central Timor. In: McWilliam, A. and Traube, E. (eds), Land and life in Timor-Leste, ethnographic essays, pp. 163-86. ANU E Press, Canberra.

Spriggs, M., O'Connor, S. and Veth, P. 2003. Vestiges of early pre-agricultural economy in the landscape of East Timor: Recent research. In: Kallen, A. and Karlström, A. (eds), Fishbones and glittering emblems: Proceedings from the EurASEEA Sigtuna Conference, pp. 49-58. Museum of Far Eastern Antiquities, Stockholm.

Trainor, C., Santana, F., Xavier, A., Xavier, F. and A. da Silva. 2003. Status of globally threatened birds and internationally significant sites in Timor-Leste (East Timor) Based on rapid participatory biodiversity assessments. Report to birdlife International - Asia Programme.

Tsing, L. 2003. Cultivating the wild: Honey-hunting and forest management in southeast Kalimantan. In Zerner, C. (ed.), Culture and the question of rights: Forest, coasts, and seas in Southeast Asia, pp. 24-56. Duke University Press, Durham.

UNESCO (United Nations Educational, Scientific and Cultural Organization). 2005. Operational Guidelines for the Implementation of the World Heritage Convention. UNESCO World Heritage Centre, Paris.

Veth, P., Spriggs, M. and O'Connor, S. 2005. The continuity of cave use in the tropics: Examples from East Timor and the Aru Islands, Maluku. Asian Perspectives 44 (1):180-92.

Whistler, A. 2001. Ecological survey and preliminary botanical inventory of the Tutuala Beach and Jaco Island protected natural areas, East Timor. Report for UNTAET.

Zerner, C. 1994. Transforming customary law and coastal management practices in the Maluku Islands, Indonesia, 1870-1992. In: Western, D. and Wright, R. (eds), Natural connections: Perspectives in community-based conservation, pp. 80-112. Island Press, Washington D.C.

Zerner, C. 2003. Moving translations: Poetics, performance, and property in Indonesia and Malaysia. In: Zerner, C.(ed.), Culture and the question of rights: Forests, coasts, and seas in Southeast Asia, pp.1-24. Duke University Press, Durham.

Zerner, C. (ed.) 2003. Culture and the question of rights: Forests, coasts and seas in Southeast Asia. Duke University Press, Durham. 